\title{
Yaşlılara Yönelik Sosyal Harcamalar: Türkiye ve AB Karşılaştırması a
}

\author{
Dilek Akbaş Akdoğan ${ }^{b, c}$
}

\section{Özet}

Günümüzde hayat şartlarındaki iyileşmeler, ülkelerin sağladıkları bakım ve sağlık hizmetlerindeki gelişmeler ve tıp alanınındaki ilerlemelerle birlikte, dünya genelinde bir yandan insan ömrü uzarken, bir yandan da toplam doğurganlık hızı düşmektedir. Bu durumun sonucu olarak hem Türkiye'de hem de dünyada yaşlı nüfusun toplam nüfus içindeki payı artış göstermektedir. $\mathrm{Bu}$ artış eğilimi, ülkelerin yaşlılara yönelik sosyal politikalarını geliştirmelerini gerekli kılmaktadır. Artan yaşlı nüfusla birlikte yaşlı bireylere sunulan hizmetlerin talebi artmakta ve aynı zamanda yaşlı bireylerce talep edilen ihtiyaçlar da değişmektedir. Çalışmanın amacı, Türkiye' de yaşlılara yönelik sosyal harcamaların gelişimini inceleyerek $\mathrm{AB}$ ülkeleri ile karşılaştırmalı bir değerlendirmesini yapmaktır. 2018 yılında sosyal harcamalarının GSYİH içindeki payı Türkiye'de \%11,9 iken AB ortalaması \%27,9 olmuştur. Türkiye'de yaşlılara yönelik harcamalar, toplam sosyal harcamalar içinde en büyük paya sahip olsa da, bu oran 2018 yılı için GSYİH'nın \%5,9'u ile sınırlı kalmıştır. Türkiye'de yaşlılara yönelik sosyal harcamalar İrlanda dışındaki tüm AB üyesi ülkelerden daha düşük bir paya sahiptir.
Anahtar Kelimeler

Yaşlı

Sosyal Harcamalar

Türkiye

\section{Makale Hakkında}

Geliş Tarihi: 28.10.2021

Kabul Tarihi: 15.12.2021

Doi: $10.18026 /$ cbayarsos.1015782

\section{Social Expenditures for the Elderly: A Comparison of Turkey and EU}

\begin{abstract}
Nowadays, with the improvements in living conditions, the developments in the care and health services provided by the countries, and the advances in the field of medicine, while the human lifespan is increasing, the total fertility rate is decreasing on the other hand. As a result of this situation, the share of the elderly population in the total population is increasing both in Turkey and around the world. This increasing trend makes it necessary for the countries to develop their social policies for the elderly. Depending on the increasing elderly population, the demand for the services provided to the elderly individuals in the society is increasing and at the same time, the needs demanded by the elderly individuals are changing. The aim of the study is to examine the development of social expenditures for the elderly in Turkey and to make a comparative evaluation with EU countries. In 2018, while the share of social expenditures in GDP was $11.9 \%$ in Turkey, the average for the EU was $27.9 \%$. Although expenditures for the elderly have the largest share in total social expenditures in Turkey, this rate was limited to 5.9\% of GDP for 2018. Social expenditures for the elderly in Turkey have a lower share than in all EU member states except Ireland.
\end{abstract}

Keywords

Elderly

Social Expenditures

Turkey

EU

\section{About Article}

Received: 28.10.2021

Accepted: 15.12.2021

Doi: $10.18026 /$ cbayarsos. 1015782

\footnotetext{
a Bu çalışma, 3-5 Aralık 2019 tarihleri arasında İstanbul'da düzenlenen "10th International Congress on Current Debates in Social Science"ta sunulan ve özet bildiri olarak yayınlanan “Türkiye’de Sosyal Devlet Anlayışı Kapsamında Yaşlılara Yönelik Sosyal Harcamalar"adlı çalışmanın güncellenmiş ve genişletilmiş halidir.

b dilek.akdogan@medeniyet.edu.tr

c Doktor Öğretim Üyesi, İstanbul Medeniyet Üniversitesi, Siyasal Bilgiler Fakültesi, Maliye bölümü ORCID: 0000-0002-8132-6971
} 


\section{Giriş}

Tüzel bir kişiliğe sahip olan devlet kurumunun varoluş gerekçelerinin başında toplumsal ihtiyaçların karşılanması gelmektedir. Devlet, ilk başlarda sınırlı sayıdaki toplumsal ihtiyacın karşılanması amacıyla kurulsa da zamanla ve toplumsal gelişmelerle birlikte hem devletin fonksiyonları değişmiş ve gelişmiş hem de karşıladığı toplumsal ihtiyaçlarda çoğalmıştır.

Devletin temel fonksiyonlarının ve buna bağlı olarak ekonomideki rolünün ne olması gerektiği geçmişten günümüze bilim insanlarınca ele alınan konular arasındadır. Bu alanda Musgrave'in (1959) çalışması devletin temel fonksiyonlarını üçe ayırarak literatürde kabul gören bir sınıflandırma olarak yerini almıştır. Musgrave çalışmasında devletin fonksiyonlarını; "kaynak dağılımı", "gelirin yeniden bölüşümü" ve "istikrar sağlama” olarak sıralamıştır. Dünya genelinde ülkelerin farklı devlet tipleri ve ekonomik sistemlerini seçtikleri ve bu bağlamda ekonomide üstlendikleri fonksiyonlarının da değiştiği görülmektedir. Ancak bilinen bir gerçektir ki devletler üstlendiği fonksiyonlar ne olursa olsun varoluşları gereği toplumsal ihtiyaçların karşılanması için birtakım harcamalar yapmak durumundadır.

Geçmişten günümüze, toplum içinde eşitsizlikler, ayrıcalıklı sınıflar ve toplumsal sorunlar var olmaktadır. Karşı karşıya kalınan sorunların toplumsal bir mesele olarak ele alınması ve mevcut sorunlara toplumsal çözümlerin üretilmesi modern çă̆ ve modern toplumlarla başlamıştır(Koray,2005,s.33). Modern toplumların doğuşuyla devletlerin toplumsal ihtiyaçların karşılanmasına yönelik mal ve hizmet üretimlerinin yanında gelir dağılımı, kaynak tahsisi, istikrar ve büyüme fonksiyonlarını da üstlenerek ekonomiye müdahalelerde bulunduğu görülmektedir. Devletin gelir dağılımı fonksiyonu temelde toplumsal adaleti sağlamak amacıyla yürüttüğü ifade edilebilir. Devletler gelir eşitsizliklerinin giderilmesinde ve gelir dağılımında adaletin sağlanması adına mali araçlarını kullanarak müdahalelerde bulunurlar. Kamu harcamaları devletlerin gelir dağılımında adaleti sağlamak adına yürüttükleri sosyal politikalarında en etkili mali araçlarından biridir.

Sosyal politika, toplumdaki kişilere hizmet ve gelir sağlayarak kişilerin refahı üzerine etki sağlamayı amaçlayan devlet tarafından yürütülen politikalar bütünü oluşturmaktadır. Sosyal sigorta, kamusal yardımlar, refah hizmetleri, konut politikası ve sosyal koruma harcamaları sosyal politikanın merkezinde yer almaktadır (Titmuss,1974,s.30). Sosyal politika uygulamalarının bir ucu gelenekler ve yardımseverlik ahlakı ile ilişki olsa da, günümüzde modern anlamda sosyal politika merhametten çok adalet, lütuftan çok hak temeline dayandırılmaktadır (Koray, 2005,s.33-34). Bu bağlamda sosyal politikalar hükümetlerce sosyal devlet olma ilkesi gereği ve demokrasi temelli yürütülmektedir.

Sosyal politika uygulamalarının en geniş vücut bulduğu devlet tipi refah devletidir. Gelişmiş ülkelerde refah devletlerinin genellikle kolektif sosyal hareketler yoluyla oluşturulmuş sosyal koruma modellerine dayalı olarak ortaya çıktığı görülmektedir. Bu bağlamda Bismark (1883) tarafından geliştirilen sosyal sigorta uygulaması modern refah devletinin başlangıcı açısından bir yapı taşı oluşturmaktadır (Spicker, 2000, s.144). Refah devletinin temel amacı sosyal refahı attırmak daha doğrusu sosyal refahı maksimize etmektir. Bu amacı gerçekleştirmek üzere vatandaşlarına sosyal güvenlik, barınma, sağlık, eğitim gibi hizmetler ve asgari bir yaşam güvencesi vermeyi hedefler. Refah devleti anlayışının bir gereği olarak özellikle devletin temel fonksiyonlarından biri olan sosyal adaletin sağlanması amaciyla devletler sosyal harcamalarda bulunmaktadır. 
Son yıllarda Türkiye özelinde ve dünya genelinde yaşlı nüfusun toplam nüfus içindeki payının önemli ölçüde artığı görülmüş ve önümüzdeki yıllarda artış trendinin devam edeceği öngörülmüştür. Değişen nüfus yapısına bağlı olarak hem dünyada hem de ülkemizde yaşlıların ihtiyaçları ve hükümetlerin sözkonusu olan bu ihtiyaçları karşılamak amacıyla sundukları hizmetler de değişime uğramıştır. Çağımızda hükümetler yaşlı bireylere sosyal güvenlik, sağlık, bakım desteği gibi belli başlı hizmetlerin dışında toplumsal yaşama katılımlarını arttırmaya yönelik hizmetler de sunmaktadır. Bu kapsamda hükümetler belirledikleri sosyal politika anlayışı içinde yaşlılara yönelik sosyal harcamalarda bulunmaktadir.

$\mathrm{Bu}$ çalışmada yaşlılara yönelik sosyal harcamalar gerekçeleriyle birlikte incelenmektedir. Öncelikle Türkiye'de yaşlılara yönelik sosyal harcamalar konusu ele alınmakta, sonrasında Türkiye ve $A B^{\prime}$ de sosyal koruma harcamaları kapsamında yaşlılara yönelik harcamaların karşılaştırmalı bir değerlendirmesi yapılmaktadır.

\section{Sosyal Politikada Bir Risk Grubu Olarak Yaşlılar ve Yaşlılı̆̆ın Artan Önemi}

1903'te Nobel ödülü alan İlya Meçnikov yaşlılığın bilimi anlamına gelen "gerontoloji" kavramını ilk kez ortaya atmış ve bu biliminin kurucusu olarak literatüre geçmiştir. Gerontoloji yaşlılık üzerine çalışmaların yapıldığı disiplinler arası bir bilim dalıdır. Yaşlılık olgusu, sosyal bilimlerin de kapsamında olan birçok bilim dalının konusuna giren, sınırlarının, evrensel bir tanımının ve sınıflandırılmasının net bir şekilde ortaya koyulmasının pek mümkün olmadığı, tartışmaya açık bir konudur. Çünkü yaşlılık soyut bir kavramdır, kişilerin ve toplumun değer yargılarına göre farklı nitelendirilebilir. Bu bağlamda yaşlılık algısı üzerinde birçok faktörün etkili olduğu görülmüştür. Yaşlılık algısı bireye, topluma, kültüre, ülkeye, belli bir zamana, eğitim seviyesine, iktisadi duruma, cinsiyete, fizyolojik ve psikolojik duruma göre değişiklik gösterebilir. Bunların dışında iklim ve beslenme gibi faktörlerde yaşlanma ve yaşlı olma üzerinde etkili olmaktadır (Cengiz, 2018,s.24; WHO, 2001,s.10).

Literatürde yaşlılığın tanımlanmasına yönelik birtakım tartışmalar mevcut olsa da, yaşlılık kavramının kronolojik tanımı yaygın olarak kullanılmaktadır. Kronolojik tanımlama belirli bir zaman dilimiyle ölçülebilen bir süreye dayanır.Yaşlılık için 65 yaş ve üzeri gibi bir yaş sınırı belirlenmesi kronolojik bir tanımlamadır. Birleşmiş Milletler(BM) yaşlı kişileri tanımlamak için 60 yaş üstünü baz almaktadır. Ayrıca BM çalışmalarında hem 60 yaş hem de 65 yaşı içeren verileri sunarak, ülkelerin politikalarını yürütürken daha kapsamlı göstergelere ulaşabilmelerini mümkün kılmaktadır. Dünya Sağlık Örgütü(DSÖ) ise 65 ve 80(ağır yaşlı) yaşlarından başlayan kategorileri kullanmaktadır (WHO,2001,s.10). OECD yaşlı nüfusu, 65 yaş ve üstü kişiler olarak tanımlamaktadır (OECD,2021a). Bu bağlamda 65 yaş, genellikle birçok gelişmiş ülkede yaşlılığa bağlı sosyal güvenlik yardımlarına hak kazanılan yaş olması sebebiyle, yaşlılık için bir referans noktası olarak kullanılmaktadır(UNFPA, 2012,s.20).

Yaş alma ile yaşlanmak olguları esasen birbirinden farklı kavramlardır. DSÖ'nün 2001 yılında yayınladığ 1 raporda buna vurgu yapılarak; normal yaş alma süreci doğal bir süreç olarak değerlendirilmiş, bu sürecin çevresel etkiler ve hastalıklardan etkilenmeden, yaşla birlikte ortaya çıkan biyolojik değişiklikleri temsil ettiği ifade edilmiştir.Yaşla ilgili değişikliklerin hepsinin olumsuz klinik etkilerinin gözlemlenmediği belirtilerek, yaşlanma süreci çevre, yaşam tarzı ve hastalık durumlarının etkilerine şiddetli bir şekilde maruz kalan bir olgu olarak 
açıklanmıştır. Ancak yaşlanma, yaş alma veya ihtiyarlık kavramlarının ve onlara bağlı süreçlerinin birbirleriyle eş anlamlı olarak kullanıldığı çalışmalarda sıklıkla görülmektedir (WHO, 2001,s.10).

Yaşlılık ile ilgili evrensel tanımlamaların mevcut olmaması, yaşlılıkta çeşitliliğin söz konusu olması ile ilişkilendirilebilir. Çünkü tipik bir yaşlı yoktur. 80 yaşındaki bazı bireylerin fiziksel ve zihinsel kapasiteleri 20 yaşındakilerin birçoğuyla oldukça benzer nitelikte olabilir veya bazı insanlar çok daha genç yaşlarda fiziksel ve zihinsel kapasitelerinde önemli düşüşler yaşayabilir.Yaşlılık üzerine yapılan tanımlamalar cinsiyete göre de farklılık arz edebilir. Örneğin emeklilik gibi yaşam akışı olayları yaşlanma geçişlerine neden olabilir. Emeklilik sistemlerinde cinsiyete göre farklı uygulamaların söz konusu olması gerçeğinden yola çıkıldığında, kadınların erkeklere nazaran daha erken yaşlılığa giriş yaptığı şeklinde bir yorumlama yapılabilir (WHO,2001,s.10). Ancak şunu belirtmek gerekir ki; bir yaşam akış olay1 olarak emeklilik genellikle yaşlılık için başlangıç noktası olarak değerlendirilse de, günümüzde yaşlılığa doğrudan giriş noktası olarak görülmemektedir (EC, 2021).

Günümüzde "yaşlanma" kavramının yanında "aktif yaşlanma" denilen yenilikçi bir kavramın ön plana çıkarılmaya çalışıldığı görülmektedir. Aktif yaşlanma refah ekonomisi kapsamında ele alınacak bir kavram olarak karşımıza çıkmaktadır. DSÖ tarafından benimsenen aktif yaşlanma kavramı; fiziksel, sosyal ve ruhsal faaliyetlerin ömür boyu sürdürülmesiyle ihtiyarlamadan yaş alma sürecini teşvik etmektedir. Yaşlanmayı olumlu bir deneyim olarak değerlendirme fikrinden filizlenen bu kavramla, insanların yaşlandıkça yaşam kalitelerini artırmak için sağlık, katılım ve güvenlik fırsatlarını optimize etme süreci hedeflenmektedir. Aktif yaşlanma, insanların yaşamları boyunca fiziksel, sosyal ve zihinsel sağlık potansiyellerini fark etmelerine ve toplumda katılımcı bireyler olarak yer almalarının yanında söz konusu bireylerin ihtiyaç duyduklarında yeterli koruma, güvenlik ve bakımın taraflarına sağlanmasını içeren bir kavramdır (UNECE, 2012,s.2; WHO,2014,s.19).

Yaşlılık olgusu bazı toplumlarda olağan bir süreç olarak değerlendirilirken, bazılarında ise bir sorun olarak görülmüştür(WHO,2021a).Esasen yaşlanan toplumlar bir sorun değil, sosyoekonomik gelişmenin bir sonucudur (OECD,2015,s.1). Aktif yaşlanma kavramıla yaşlılığın bir sorun olarak algılanmasının önüne geçilerek, olumlu bir deneyim olarak değerlendirilmesi amaçlanmaktadır. Aktif yaşlanma, yaşlı bireylerin toplum üzerinde bir yük olarak görülmesinin yanlışlığına vurgu yaparak birçok alanda katılımcı, üretken, yenilikçi küresel çă̆ın gerekliliklerini yerine getirebilen bireyler üzerine kurulu bir olgu olarak değerlendirilebilir.

Aktif yaşlanma kavramı bireylerin refahı ile güçlü bir şekilde ilişkilidir. Ancak kişilerin refahı yalnızca bireysel bir lüks olarak değerlendirilmemiştir. Bireylerin işgücü piyasasına katılımının arttırılması hedeflenmekte ve katılımın artmasıyla örneğin sağlık harcamalarının azalması gibi nihai toplumsal faydaları beklenmektedir. Aktif yaşlanma kavramıyla işgücü piyasasına katılım, sosyal içerme ve sağlık gibi çeşitli politik alanlarda hükümetlerin yürütmekte olduğu yaşlanma politikalarının düzenlenmesi amaçlanır (UNECE,2012,s.2).

Son yıllarda gerek dünyada gerek ülkemizde yaşlı nüfusun toplam nüfus içindeki payı önemli ölçüde artmıştır. Hükümetlerin yaşlılara yönelik politikalara ağırlık vermesinin temel nedenini bu artış eğilimidir. Demografik devrim diye tabir edebileceğimiz dünya genelinde 
yaşanmakta olan bu değişimin nedeni iki temele oturtulabilir.Bunlar; ölüm oranlarındaki ve doğurganlık oranlarındaki düşüşlerdir. Dünya nüfusunda, doğurganlık oranlarındaki düşüşlere bağlı olarak bir yandan çocukların payı azalırken, diğer yandan büyük ölçüde sağlık hizmetlerinin gelişmesiyle yaşlı insanların payı artmaktadır. Yaşlı insanların ölüm olanlarındaki düşüş ve dolayısıyla insan ömrünün uzaması genel anlamda bir başarı olarak değerlendirilebilir. Ancak bu başarı, yaşlı nüfusun öncelikli ihtiyaçları olan sağlık ve sosyal bakım hizmetlerinin talebinde önemli artışları beraberinde getirmektedir. Dünya genelinde sözü edilen hizmetlerin talebindeki artış eğilimi ülkelerin bu alandaki politikalarını geliştirmelerini gerekli kılmaktadır. Emekli maaşları ve yaşlılık aylıkları gibi sosyal güvenlik hizmetleri kapsamındaki kamu harcamaları genellikle bu alanda en büyük paya sahiptir. Ayrıca yaşlı bireylerin ihtiyaçları ve bu kapsamda yaşlı bireylere sunulan hizmetler de değişmiştir(EC, 2021). Yaşlıların savunmasız durumları göz önüne alındığında, devletler ilgili önlemleri almakla mükelleftirler.Söz konusu önlemler aynı zamanda sosyal güvenlik programlarının oluşturulması anlamına da gelmektedir (Geyik, 2020,s.57).

DSÖ 2020 yılında 1 milyar olan 60 yaş ve üzeri toplam nüfusun 2050'de 2 milyar olacağını öngörmektedir. 2015 ile 2050 yılları arasında, dünyadaki 60 yaş ve üzeri toplam nüfus oranının neredeyse ikiye katlanarak \% 12'den \% 22'ye çıkması beklenmektedir. 2050 yılında yaşlıların \% 80'inin düşük ve orta gelirli ülkelerde yaşıyor olacağ ${ }_{1}$ öngörülmektedir. Nüfus yaşlanma hızı geçmişe göre çok daha fazla artmıştır. Ülkeler, başta sağlık ve sosyal sistemleri olmak üzere ilişkili tüm sistemlerini demografik devrim diye tabir edilen bu değişime en iyi biçimde ayak uyduracak şekilde yeniden yapılandırmalıdır (WHO, 2021a). Tabi bu süreçte ülkelerin büyük zorluklarla karşı karşıya kalacağı beklenen bir gerçektir. Hükümetlerin yaşlılara yönelik sosyal politikalarının ağırlığının artışı günümüz dünyası koşullarının bir gerekliliği olarak karşımıza çıkmaktadır.

\section{Yaşlılara Yönelik Sosyal Politika İhtiyacının Gerekçeleri}

Yaşlılara yönelik sosyal politikaların geliştirilmesini belli başlı nedenlere dayanarak açıklamak mümkündür. Bu nedenler; demogafik, ekonomik ve sosyal nedenler olarak üç ana başlık altında toplanabilir.

\subsection{Demografik Nedenler}

Önceki bölümde ayrıntılı bir şekilde açıklanan demografik nedenler, dünya genelinde yaşlı bireylerin toplam nüfus içindeki payının artması sonucunda demografik dönüşüm diye tabir edilen süreçle ilgilidir. Artık nüfus hızlı bir şekilde yaşlanmakta yani nüfusun içindeki yaşlı bireylerin oranı hızla çoğalmaktadır. Nüfusun önemli bir kısmını oluşturan yaşlı bireylere yönelik sosyal politikaların ağırlığı dünya genelinde artmaktadır. Önümüzdeki yıllar için hazırlanan nüfus projeksyonları yaşlı nüfusun toplam nüfus içindeki artış eğiliminin hızla devam edeceğini öngörmektedir(OECD, 2021b). Artan yaşlı nüfus, ülkelerin kamu politikası uygulamalarında yaşlılara yönelik sosyal politikalarının ağırlığını arttırmalarını gerekli kilmaktadir.

\subsection{Ekonomik Nedenler}

Ekonomik nedenler yaşlı bağımlılık oranıyla ilişkili olarak değerlendirilebilir. Yaşlı bağımlılık 
oranı 65 yaş ve üstü kişilerin sayısının(genellikle ekonomik olarak aktif olmadıkları yaş) 15 ile 64 yaş arasındaki kişilerin sayısına oranıdır. Bu değer, 15-64 yaş grubundaki yetişkin nüfustaki her yüz kişi için 65 ve üstü yaş grubundaki kişi sayısıdır(Eurostat, 2021a).

Dünyada ve Türkiye'de yaşlı bağımlılık oranında son zamanlarda önemli artışlar yaşandığı görülmektedir.Türkiye' de 2019 yılında yaşlı bağımlılık oranı \%13.4'e yükselmiştir (AÇSHB,2020). Nüfus projeksyonlarının öngördüğü üzere, uzun vadede doğurganlık düşmeye devam ederse, çalışma yaşındaki nüfusun toplam nüfus içindeki payı azalırken, yaşlıların toplam nüfus içindeki payı artacaktır. Bu durum artan yaşlı bağımlılık oranına yol açacaktır. Artan yaşlı bağımlılık oranı da toplum üzerinde "demografik yük" diye adlandırılan bir olgu yaratır. Söz konusu durum demografik devrimin kaçınılmaz bir sonucu olarak öngörülmekte ve birçok ülkenin bu sorunla yüz yüze kalacağı beklenmektedir (WHO, 2021b).

Yaşlılık bireyin çalışma gücünün azalmasına bağlı olarak, işgücü piyasalarından çekilmesi sonucunu doğurmakta(emeklilik), yaşlı bireylerin işgücü piyasalarından çekilmeleri ise üretici grubundan tüketici grubuna geçmelerine neden olmaktadır. Tüketici grubundaki yaşlı bireylerin milli gelire katkısı olmamakla birlikte başta sosyal güvenlik hizmetleri olmak üzere çeşitli hizmetlere olan talepleri hükümetlerin sosyal harcamalarını arttırmaktadır. Yaşlı nüfusun işgücü piyasasından çekilerek kamu gelirlerini azaltması ve daha fazla sosyal harcamalar beklentisi içinde olması ekonomideki makroekonomik büyüklükler ve dengeler üzerinde olumsuz etkiler yaratacaktır.Gerek ülkelerin büyüme ve kalkınma hedefleri, gerek istihdam politikaları veyahut ekonomideki yatırımlar ve tasarruflar artan kamu harcamalarına bağlı olarak etkilenecektir. Bu bağlamda demografik devrim diye tabir edilen süreçte hükümetler özellikle makroekonomik değişkenleri dengede tutabilmek için yaşlılara yönelik sosyal politikalarını geliştirmelidir.

\subsection{Sosyal Nedenler: Aile Yapısındaki Dönüşümm}

Yaşlı bireylerin artan nüfusuna bağlı olarak yaşanmakta olan demografik değişim elbette ki aile yapılarını ve ilişkilerini etkilemektedir. Yaşam beklentisindeki gelişmeler, çok kuşaklı ailelerin yapısını değiştirmiştir. Nesiller içinde ve arasında ortak yaşam sürdürme, hem aile bireylerinin yaşam süreleri boyunca aralarındaki duygusal bağlarını daha uzun süreli kurabilmelerine, hem de bakım desteğini de içeren destek alışverişlerinde daha uzun süreli bulunabilmelerini imkan sağlamıştır. Ayrıca doğurganlık oranlarının azalması, boşanma, yeniden evlenme ve üvey aile oluşumu oranlarının artması hem kuşaklararası, hem de eşler veya kardeşler arasındaki ilişkileri değiştirmiştir. Akrabalık yapılarındaki artan çeşitliliğin yaşlı aile üyelerine destek ve bakım verme üzerindeki etkisi henüz çok net olarak çözümlenmemiş olmakla birlikte bu alanda önemli kaygılar yaratmıştır (Silverstein\&Giarrusso,2010).

Yaşlı bireylerinde içinde yer aldığı geleneksel büyük aile yapısından çekirdek aileye doğru bir küçülme yaşanırken, çekirdek aile oluşumu dışında bireylerin farklı davranış ve tutumlarına da rastlanmaktadır. Değişen dünyayla birlikte aile yapılarının, rollerinin ve ilişkilerinin doğasında da bir değişim yaşanarak evlilik, birlikte yaşama, bekar ebeveynlik, boşanma ve çocuksuzluk gibi bireylerin farklı tercihlerde ve tutumlarda bulundukları görülmektedir. Günümüzde evlilik halen aile yapısının en baskın biçimiyken, bazı toplumlarda artık evlilik 
bir aile olarak yaşamanın ve çocuk sahibi olmanın mümkün olduğu tek çerçeve olarak görülmemeye başlanmıştır. Ailelerin boyut, karakter ve konum bakımından giderek daha heterojen ve karmaşık bir hale geldiği söylenebilir (Government Office for Science,2016). Böylesine karmaşık bir yapıda yaşlı bireylerin yerinin nasıl olacağı konusu ise belirsizlik içindedir. Son yıllarda toplum içinde ailenin üstlendiği misyon, bireylerine sağladığ 1 destek ve bakım değişime uğramış, demografik dönüşümle birlikte şekillenmeye devam etmektedir. Söz konusu olan bu demografik devrim toplumun en küçük birimi olan ailelerin rolünü değiştirebilecek bir potansiyele sahiptir. Bu durum, doğrudan aile ve dolaylı olarak ailelerle ilişkili sosyal politikaların revize edilmesine neden olabilir. Hükümetler yaşlılara yönelik yürütülen sosyal politikalarını çağın ihtiyaçları doğrultusunda düzenlemeli, değişen aile yapısı ve bağları hesaba katılarak sosyal politikaların ağırlığı belirlenmelidir.

Yukarıda bahsedilen demografik, ekonomik ve sosyal nedenlerin dışında insani gerekçelerle ve sosyal devlet ilkesi gereği olarak yaşlılara yönelik sosyal politikalar geliştirilmektedir (Taşç1, 2010,s.177).

\section{Sosyal Harcamalar}

Sosyal devlet anlayışının bir gereği olarak refah düzeyini arttırmak ve gelir dağılımında adaleti sağlamak amacıyla devlet tarafından vatandaşlarına sosyal hizmetler sunulmaktadır. Sözü edilen sosyal hizmetlerin gerçekleşebilmesi için devlet sosyal harcamalarda bulunmaktadırlar. Sosyal harcamaların sahip olduğu pozitif dışsallıklar sosyal harcamaların artırılması gerekliliğinin en açık göstergelerinden birisidir. Dolayısıyla maliye politikalarının dizaynında toplumsal adaletin sağlanabilmesi adına sosyal harcamalar lehine bir kompozisyon tercih edilmelidir(Geyik\&Şeren,2021,s.17-18). Günümüzde devletler sosyal bütçe aracıyla sosyal harcamaların kamu bütçesi içinde eşitlik, gelir dağılımı, yoksulluk vb. kriterlere göre yeniden düzenlenmesini hedeflemektedir(Altuğ, 2020,s.214). Bu hedef doğrultusunda sosyal bütçelemenin iki temel amaca hizmet ettiği ifade edilebilir. Birincisi sosyal politika planlama sürecinin bir parçası olmak, ikincisi ise devletin finansal planlama sürecinin bir parçası olmaktır. Bu bağlamda sosyal bütçe ulusal finansal bir makro araç olarak değerlendirilebilir (Scholz vd., 2000,s.7).

Sosyal harcama kavramının genel uzlaşma sağlanabilmiş tek bir tanımı yapmak pek mümkün değildir. Kamu harcamalarının sosyalliğinin nerede başlayıp nerede bittiğini ortaya koyacak objektif ölçütlerin belirlenmesindeki zorluklar nedeniyle, hangi harcamaların sosyal harcama olarak kabul edileceği konusu tartışmaya açıktır. Sosyal harcamaların kapsamı ülkelerin gelişmişlik düzeylerinde ve sosyokültürel yapılarına göre farklılık gösterebilir. Kavramın net bir tanımlaması zor olsa da sosyal harcamaların temelde sosyal gereksinimleri karşılamak ve sosyal sorunlara çözüm getirmek şeklinde iki temel işlevi olduğu görülmektedir (Erdoğdu\&Yenigün, 2008, s.9).

Kamu harcamalarından hangi harcamaların sosyal harcama olarak değerlendirileceğini belirlemeye yönelik uluslararası üç bilgi sistemi mevcuttur. Avrupa Birliği (AB), Ekonomik Kalkınma ve İşbirliği Örgütü (OECD) ve Uluslararası Çalışma Örgütü'nün (ILO) her biri, sosyal koruma harcamalarının izlenmesinde aşağıda yer alan üç farklı yönteme dayalı bilgi sistemlerine sahiptir. 
- Avrupa Birleştirilmiş Sosyal Koruma İstatistikleri Sistemi (ESSPROS, European System of Integrated Social Protection Statistics-EUROSTAT)

- Sosyal Harcamalar Veri Tabanı (SOCX, Social Expenditure Database-OECD)

- Uluslararası İş Örgütü Metodolojisi (SPERS,Social Protection Expenditure and Performance Reviews-ILO)

Tablo 1. Sosyal Harcamaların Hesaplanmasında Kullanılan Metodolojiler

\begin{tabular}{|c|c|c|c|c|c|}
\hline \multicolumn{2}{|c|}{ Avrupa Birliği } & \multicolumn{2}{|c|}{$\begin{array}{l}\text { Ekonomik Kalkınma ve } \\
\text { İşbirliği Örgütü }\end{array}$} & \multicolumn{2}{|c|}{ Uluslararası Çalışma Örgütü } \\
\hline 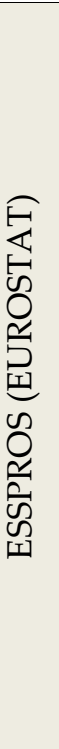 & $\begin{array}{l}\text {-Hastalık/Sağlık } \\
\text {-Engellilik } \\
\text {-Malullük } \\
\text {-Aile/Çocuk } \\
\text {-İş kazası } \\
\text {-Yaşlılık } \\
\text {-Konut } \\
\text {-Sosyal Dışlanma }\end{array}$ & 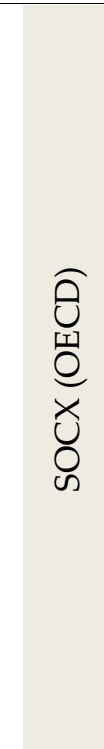 & $\begin{array}{l}\text {-Yaşlılık } \\
\text {-Malullük } \\
\text {-Engellilik } \\
\text {-Sağlık } \\
\text {-Aile } \\
\text {-Aktif işgücü } \\
\text { programları } \\
\text {-İssizlik } \\
\text {-Konut } \\
\text {-Diğer sosyal politika } \\
\text { alanları }\end{array}$ & 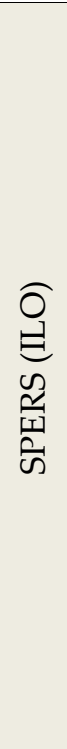 & $\begin{array}{l}\text {-Sağlık } \\
\text {-Hastalık } \\
\text {-Engellilik } \\
\text {-Malullük } \\
\text {-İş kazası } \\
\text {-Yaşlılık } \\
\text {-Aile ve Çocuk } \\
\text {-İşsizlik ve işgücü } \\
\text { piyasası politikası } \\
\text {-İşgücü piyasası } \\
\text { programları } \\
\text {-Konut } \\
\text {-Sosyal yardım ve } \\
\text { diğerleri } \\
\text {-Temel Eğitim } \\
\text {-Gıda ve Beslenme }\end{array}$ \\
\hline
\end{tabular}

Kaynak: Şeker, 2011,s.19.

Tablo 1'de görüldüğü üzere üç metodoloji arasında birtakım farklılıklar bulunmaktadır. ESSPROS ve SOCX metodolojilerinde sosyal harcama kavramı daha dar değerlendirilmektedir. Bu iki yöntemde de eğitim harcamaları hesaplamaya dahil edilmemiştir. ILO'nun metodolojisi eğitim harcamalarını da içine alan biraz daha geniş kapsamlı bir yöntemdir. Sosyal harcamaların hesaplanmasında kullanılan her bir metodolojide de yaşlılık değerlendirmeye alınacak bir kıstastır.

ESSPROS, 1970'lerin sonlarında AB üyeleri için sosyal harcamalar alanında ortak bir çerçeve geliştirilen bir metodolojidir(Eurostat, 2019,s.92). ESSPROS sosyal harcamalarla yapılan sosyal yardımları, hanehalklarını birtakım risklerin veya ihtiyaçların mali yükünden kurtarmak amacıyla nakdi veya ayni olarak yapılan transferler olarak tanımlanmıştır (EC, 2016,s.6).

SOCX metodolojisine göre ise sosyal harcamalar, sosyal amaçlarla yapılan nakdi yardımlar, mal ve hizmetlerin doğrudan ayni sağlanması ve sosyal amaçlı vergi indirimlerinden oluşmaktadır. Yardımlar düşük gelirli hanelere, yaşlılara, engellilere, hastalara, işsizlere veya gençlere yönelik olabilir. Bir harcamanın "sosyal" olarak kabul edilebilmesi için belirleyici olan husus, harcamalarla uygulanan programların ya haneler arasında kaynakların yeniden dağıtımına yönelik olması ya da söz konusu programlara zorunlu katılımın mevcut olmasıdır (OECD, 2021c). 


\section{Türkiye'de Sosyal Koruma Harcamaları}

Türkiye'de sosyal koruma harcamalarının hesaplanmasında ve izlenmesinde $A B$ tarafından geliştirilmiş olan ESSPROS yöntemi kullanılmaktadır. Türkiye AB istatistikleriyle uyumlu olmak amacıyla, 2014 yılından itibaren sosyal koruma harcamaları istatistiklerini yayınlamaya başlamıştır(Yentürk,2018,s.30). Bu istatistikler TÜİK tarafından hazırlanmaktadır. Türkiye'nin uluslararası bir metodoloji olan ESSPROS yöntemini kullanması bu çalışmanın uluslararası bir karşılaştırmaya dayanabilmesine imkan sağlamıştır. Türkiye'de sosyal harcamaların gelişimiyle ilgili pek çok çalışma mevcuttur. Çalışmalar dönemsel aralıkları için sosyal harcamaların eğilimini analiz etmiştir (Dökmen\&Kaplan, 2018; Arısoy vd. 2010; Görkem, 2019; Topuz, 2009; Doğan\&Kabayel, 2017; Öztürk 2020; İlgün, 2015, Koç, 2019).

Türkiye'de sosyal harcamaların kapsamını belirlenmesine yönelik en önemli gelişme olarak 5018 sayılı Kamu Mali Yönetimi ve Kontrol Kanunu'nun kabulü gösterilebilir (Yentürk, 2018,s.31). Temelde kamu mali yönetiminde mali saydamlık ve hesap verme sorumluluğunun arttırılmasını hedef alan bu kanunla analitik bütçe sınıflandırılması getirilmiştir. Analitik bütçe sınıflandırılması 2004 yılında konsolide bütçe kapsamındaki idarelerde, 2006 yılından itibaren ise merkezi yönetim kapsamındaki idareler, sosyal güvenlik kurumları ve mahalli idarelerde uygulamaya konulmuştur(SBB,2020a,s.255). 5018 sayılı kanunla kamu harcamalarının fonksiyonel(işlevsel) sınıflandırılmasına imkan tanımış ve fonksiyonel sınıflandırmayla kamu harcamaları "sağlık hizmetleri", "sosyal güvenlik ve sosyal yardım", "eğitim hizmetleri" gibi çeşitli alt harcama gruplarında incelenebilmiştir. Bu uygulama sosyal koruma harcamalarının hesaplanması için önemli bir aşama olarak değerlendirilebilir (Yentürk, 2018,s.31). Ancak analitik bütçe sınıflandırmasıyla istenilen sonuçlara ulaşılamadığ1 ve kaynak tahsisi kararlarında genellikle girdilere odaklanılması sebebiyle aşamalı olarak bırakılmaya başlanmıştır(SBB, 2020b, s.12-13). 2021 yılı merkezi yönetim bütçesi, performans esaslı program bütçeye uygun olarak hazırlanmış ve TBMM'de kabul edilmiştir (SBB, 2021a,s.2).

Sosyal koruma harcamalarının ESSPROS yöntemiyle hesaplanmasında öncelikle kamu tüzel kişilerinin en büyüğü ve en önemli kısımını oluşturan merkezi yönetim kapsamındaki kamu idarelerince yapılan sosyal harcamalar dahil edilmektedir. Bu bağlamda "genel devlet"e dahil olan kurumlar hesaba katılıyor olmakta ve merkezi yönetim kapsamındaki idarelerin dişında Sosyal Güvenlik Kurumu, İşsizlik Sigortası Fonu, Sosyal Yardımlaşma ve Dayanışmayı Teşvik Fonu (SYDTF) tarafından yapılan harcamalar da kapsama alınmaktadır (Yentürk, 2018,s.31).

Türkiye'nin nüfusu TÜİK'in yayınladığ 2020 sonu verilerine göre 83 milyon 614 bin 362 kişidir. 2019 yılında binde 13,9 olarak hesaplanan yıllık nüfus artış hızı, 2020 yılında binde 5,5 olarak hesaplanmıştır. Türkiye nüfusunun ortanca yaşının 2019 yılında 32,4 olduğu, 2020 yılına gelindiğinde ise 32,7'ye yükseldiği görülmektedir. Grafik 1, 2007 ve 2020 yıllarında Türkiye'de nüfusun yaş gruplarına göre dağılımını göstermektedir. 
Grafik 1. Türkiye' de Nüfusun Yaş Gruplarına Göre Dağılımı 2007, 2020

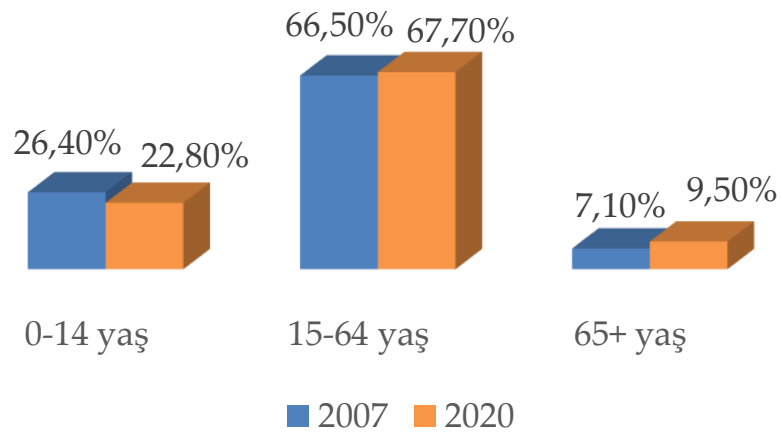

Kaynak: TÜIK, 2021a.

2007 yılında \%7,1, 2019 yılında \%9,2 olan 65 yaş ve üzeri nüfusun toplam nüfus içerisindeki oranı 2020 yılında \%9,5'e yükselmiştir. Aşağıdaki Grafik 2 Türkiye'de son beş yıla ait yaş bağımlılık oranlarını göstermektedir.

Grafik 2. Türkiye'de Yaş Bağımlılık Oranları, 2016-2020

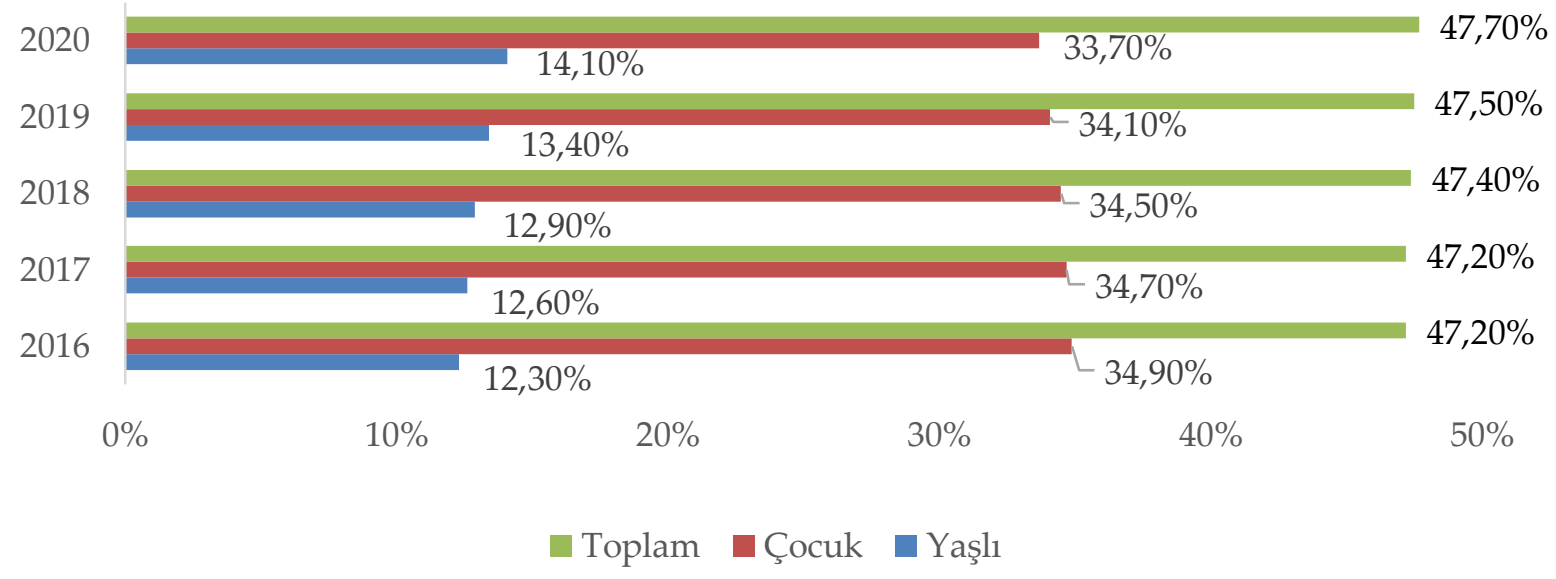

Kaynak: TÜIK, 2020.

Çalışan birey başına düşen yaşlı birey sayısını ölçen yaşlı bağımlılık oranı 2016 yılında \%12,3 olarak hesaplanmıştır. 2020 yılına gelindiğinde bu oran \%14,1'e yükselmiştir. Grafik 2'ye göre 2020 yılında Türkiye'de çalışma çağındaki her 100 kişi, 33,7 çocuğa ve 14,1 yaşlıya bakmak durumundadır.

TÜİK'in 2020 yılının sonunda yayınladığı istatistiklere göre Türkiye' de 2019 yılında sosyal korumaya yönelik 542 milyar 2 milyon TL harcanmıştır. Yapılan bu hesaplama kapsamında, sosyal koruma harcamalarl; sosyal koruma yardımları, idari masraflar ve diğer harcamalar olmak üzere alt gruplara ayrılmıştır.Sosyal koruma yardımları ise, 8 risk/ihtiyaç grubu (hastalık/sağlık bakımı, engelli/malül, emekli/yaşlı, dul/yetim, aile/çocuk, işsizlik, konut ile sosyal dışlanma b.y.s) için yapılan sosyal yardımları kapsamaktadır (TÜİK, 2020). 
2019 yılında Türkiye' de sosyal koruma harcamalarının bir önceki yıla (2018) göre \%20,8 arttığ görülmektedir. Tablo 2, 2018 ve 2019 yıllarında Türkiye'de sosyal koruma harcamalarının payını ve dağılımını göstermektedir (TÜİK, 2020).

Tablo 2. Türkiye' de Sosyal Koruma Harcamalarının Dağılımı, 2018, 2019

\begin{tabular}{crrrr}
\hline & $\begin{array}{r}\mathbf{2 0 1 8}^{(\mathbf{r})} \\
\text { Brüt (Milyon TL) }\end{array}$ & $\begin{array}{r}\text { Pay \% } \\
\text { Brüt (Milyon TL) }\end{array}$ & Pay \% \\
\hline Sosyal Koruma Harcamaları Toplamı & & & & \\
& 448727 & 100,0 & 542002 & 100,0 \\
\hline İdari masraflar ve diğer harcamalar & 6700 & 1,5 & 8834 & 1,6 \\
\hline Sosyal koruma yardımları toplamı & 442027 & 98,5 & 533168 & 98,4 \\
\hline Hastalık/sağllk bakımı & 121755 & 27,1 & 146035 & 26,9 \\
Engelli/malül & 14840 & 3,3 & 18030 & 3,3 \\
Emekli/yaşlı & 219939 & 49,0 & 263078 & 48,5 \\
Dul/yetim & 52262 & 11,6 & 63586 & 11,7 \\
Aile/çocuk & 16986 & 3,8 & 23177 & 4,3 \\
İşsizlik & 10358 & 2,3 & 15732 & 2,9 \\
Sosyal dışlanma b.y.s* & 5887 & 1,3 & 3529 & 0,7 \\
\hline . & & & &
\end{tabular}

Kaynak: TÜIK, 2020.

Tablodaki rakamlar yuvarlamalardan dolayı toplamı vermeyebilir.

(r): 2019 yılı verileri idari kayıtların güncellenmesi nedeniyle revise edilmiştir.

*b.y.s: başka yerde sinıflandırılamayan.

2019 yılında Türkiye'deki sosyal koruma harcamalarının dağılımına bakıldığında, \%98,4'ünü(533 milyar 168 milyonTL) sosyal koruma yardımları oluşturmaktadır. Sosyal koruma yardımlarında en büyük harcamasını ise 263 milyar 78 milyonTL'lik bir tutarla emekli/yaşlılara yapılan harcamalar oluşturmaktadır. Dağılımda emekli/yaşlılara yapılan harcamalardan sonra ikinci sırada 146 milyar 35 milyon TL ile hastalı/sağlık bakımına yapılan harcamalar yer almaktadır (TÜİK, 2020).

Geçmişten günümüze sosyal koruma harcamalarının düzeyine bakıldığında, bu harcamaların düzenli bir artış eğilimi içinde olduğu görülmektedir. Grafik 3, Türkiye'de sosyal koruma harcamalarının 2000-2019 yılları arasındaki değerlerini göstermektedir. 2000 yılında 14 milyarTL olan sosyal koruma harcamaları, 2010 yılında 148 milyar TL'ye, 2019 yılında ise 542 milyarTL'ye yükselmiştir. 
Grafik 3. Türkiye'de Sosyal Koruma Harcamaları, 2000-2019

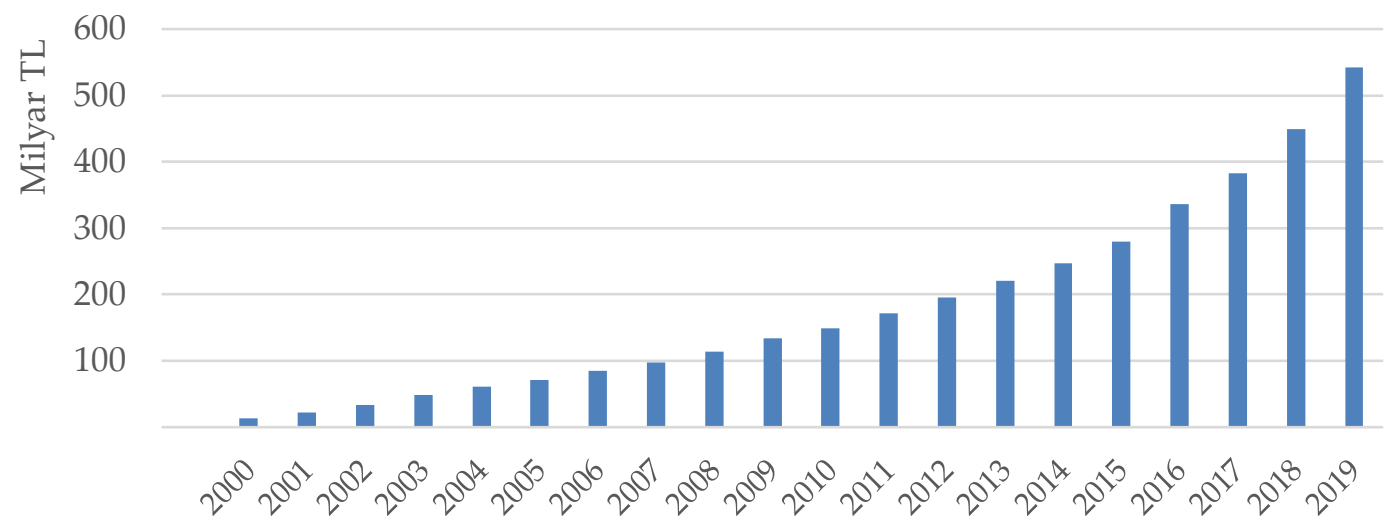

Kaynak: TÜIK, 2020.

Sosyal koruma harcamalarının GSYİH'ye oranı tablo 3'de gösterilmektedir. 2018 yılında Türkiye'de sosyal koruma harcamalarının GSYH'ye oranı \%11,9 olarak hesaplanmıştır. Bu oran 2019 yılında \%12,5'e çıkmıştır. Sosyal koruma harcamalarının risk/ihtiyaç grupları bazında dağılımına bakıldığında, emekli ve yaşlılara yönelik harcamalar 2019 yılında \%6,1'lik pay ile dağılım içinde en yüksek değere sahiptir. Sıralamada daha sonra \%3,4 oranla hastalık ve sağlık bakımı harcamaları, \%1,5 oranla dul ve yetim harcamaları gelmektedir. Engelli/mamül $(\% 0,4)$, aile/çocuk $(\% 0,5)$, işsizlik $(\% 0,4)$ ve sosyal dişlanma b.y.s. harcamalarının her birinin GSYİH'ye oranı ise yüzde birin altında kalmıştır.

Tablo 3. Türkiye'de Sosyal koruma harcamalarının GSYH'ye oranı (\%), 2018, 2019

\begin{tabular}{ccc}
\hline & $2018^{(\mathrm{r})}$ & 2019 \\
\hline Sosyal Koruma Harcamaları Toplamı & $\mathbf{1 1 , 9}$ & $\mathbf{1 2 , 5}$ \\
\hline İdari masraflar ve diğer harcamalar & 0,2 & 0,2 \\
\hline Sosyal koruma yardımları toplamı & $\mathbf{1 1 , 8}$ & $\mathbf{1 2 , 3}$ \\
\hline Hastalık/sağlık bakımı & 3,2 & 3,4 \\
Engelli/malül & 0,4 & 0,4 \\
Emekli/yaşlı & 5,9 & 6,1 \\
Dul/yetim & 1,4 & 1,5 \\
Aile/çocuk & 0,5 & 0,5 \\
İşsizlik & 0,3 & 0,4 \\
Sosyal dışlanma b.y.s* & 0,2 & 0,1 \\
\hline
\end{tabular}

Kaynak: TÜIK, 2020.

Tablodaki rakamlar yuvarlamalardan dolayı toplamı vermeyebilir.

(r): 2019 yılı verileri idari kayıtların güncellenmesi nedeniyle revise edilmiştir.

*b.y.s: başka yerde sinıflandırılamayan.

Tablo 4'de 20018-2019 yıllarında sosyal koruma kapsamında maaş alan kişi sayıları yer almaktadır. 2018 yılında maaş alan toplam kişi sayısı 13.766 .000 iken, 2019 yılında bu sayı 14.089.000'e çıkmıştır. 2019 yılında 9.849.000 kişi emekli/yaşlı maaşı, 3.759.000 kişi dul/yetim maaşı, 864.000 kişi engelli/malül maaşı almıştır. 2019 yılında Türkiye'de sosyal koruma 
harcamaları kapsamında maaş alan kişilerin dağılımına bakıldığında emekli/yaşlı maaşı alanların (\%70) en yüksek paya sahip olduğu görülmektedir (TÜİK, 2020).

Tablo 4. Türkiye' de Sosyal Koruma Kapsamında Maaş Alan Kişi Sayısı (bin kişi)

\begin{tabular}{lrrrrrr}
\hline & \multicolumn{3}{c}{$2018^{(\mathrm{r})}$} & \multicolumn{3}{c}{2019} \\
& Toplam & Erkek & Kadın & Toplam & Erkek & Kadın \\
\hline Toplam maaş alan kişi sayısı & 13.766 & 7.861 & 5.905 & 14.089 & 8.031 & 6.058 \\
Emekli/yaşlı maaşı alan kişi sayısı & 9.514 & 7.144 & 2.370 & 9.849 & 7.313 & 2.536 \\
Engelli/malül maaşı alan kişi sayısı & 856 & 503 & 353 & 864 & 504 & 360 \\
Dul/yetim maaşı alan kişi sayısı & 3.758 & 264 & 3.494 & 3.759 & 267 & 3.492 \\
Toplam maaş yardımı sayısı & 14.389 & 7.922 & 6.467 & 14.747 & 8.096 & 6.651 \\
\hline
\end{tabular}

Kaynak: TÜIK, 2020.

(r): 2018 yılı verileri idari kayıtların güncellenmesi nedeniyle revise edilmiştir.

Sosyal koruma harcamaları, hükümetlerce üretim amaçlı yapılan harcamalar olmayıp yeniden dağıtım amaçlı yapılan harcamalardır (EC,2012, s.17). Sosyal koruma harcamaları kapsamında değerlendirilen sosyal yardımlar ayni ve nakdi olmak üzere iki grupta incelenebilir. Hanehalkları ve bireylerin tanımlanmış risk ve ihtiyaç yüklerini hafifletmek amacıyla sosyal koruma düzenlemeleri kapsamında gerçekleştirilen ayni ve nakdi tüm transferler sosyal koruma harcamalarını oluşturmaktadır. Sosyal koruma yardımlarının bir diğer sınıflandırılması da şarta bağlı olup olmamasına göre yapılmaktadır. Şartlı sosyal koruma yardımları, gelir ve/veya varlıkları belirli bir düzeyin altında olma şartına bağlı olarak yararlanıcılara sağlanan sosyal yardımları kapsamaktadır. Bu yardımlar genellikle devlet katkıları ile finanse edilmekte ve yararlanıcıların katkısı talep edilmemektedir. Şartsız yardımlar ise, kişinin gelir ve/veya refah düzeyine bakılmaksızın yapılan yardımlar olarak tanımlanabilir (TÜİK, 2020). Aşağıdaki grafik 4, Türkiye'de 2018 ve 2019 yıllarında türlerine göre sosyal koruma yardımlarının dağılımını göstermektedir.

Grafik 4. Türlerine Göre Sosyal Koruma Yardımları (\%), 2018, 2019
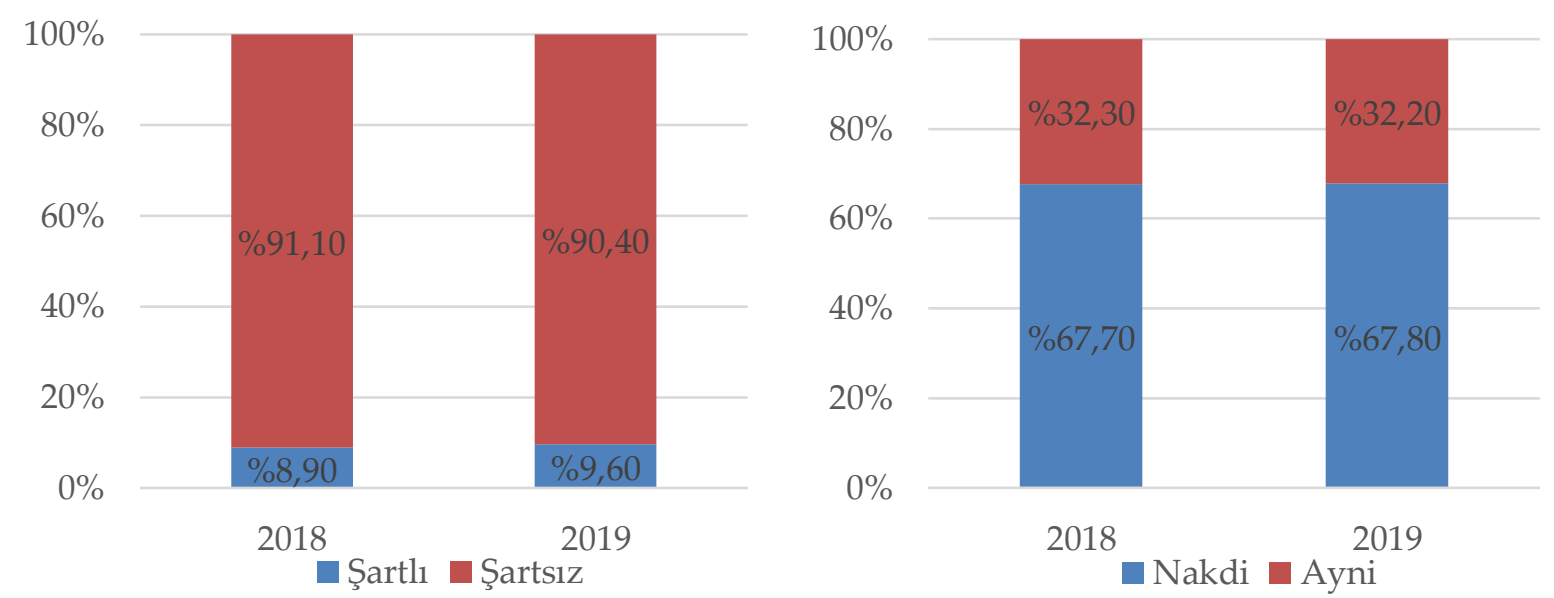

Kaynak: TÜIK, 2020. 
Sosyal koruma harcamalarının finansman kaynakları çeşitlilik göstermektedir. Türkiye'de sosyal koruma harcamalarının yapıldığı risk/ihtiyaç grubuna karşı müdahalede bulunan resmi ve özel kurum/kuruluşlar şu şekilde sıralanabilir (TÜİK, 2020).

1. Sosyal güvenlik kuruluşları,

2. Merkezi hükümet,

3. Belediyeler,

4. Sivil toplum kuruluşları,

5. Resmi veya özel işverenler (devletin işveren olduğu durumlar da dahildir).

Grafik 5'de Türkiye'de 2019 yılında sosyal koruma gelirlerinin dağılımı gösterilmiştir. Esasen sosyal koruma gelirleri üç ana gruba ayrılabilir. Bunlar "devlet katkıları", "sosyal katkılar" ve "diğer gelirler"dir. Diğer gelirler bu gruplandırma içinde en düşük orana sahip olan gelir türüdür, 2019 yılında \%8,26 olarak hesaplanmıştır. Devlet katkıları 2019 yılında \%40,21 oranına sahip olmuştur. Sosyal katkıların oranı ise \%51,52' dir. Sosyal katkılar, "işveren sosyal katkısı" ve "sosyal koruma kapsamındaki bireyler tarafından yapılan sosyal katkılar" olmak üzere iki grupta incelenebilir. 2019 yılında işveren sosyal katkıs1 \%27,91, sosyal koruma kapsamındaki bireyler tarafından yapılan sosyal katkılar ise \%23,60 olarak hesaplanmıştır.

Grafik 5. Türlerine Göre Sosyal Koruma Gelirlerinin Dağılımı (\%), 2019

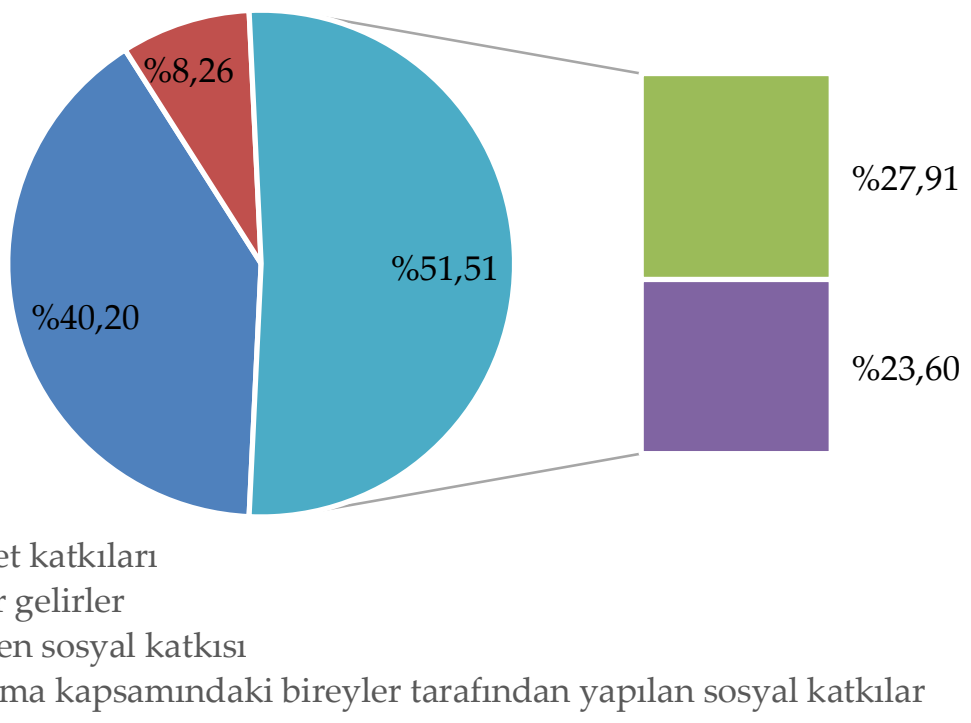

Kaynak: TÜIK, 2020.

*Yüzdedeki küsuratlardan dolayı toplam \%100'ü vermeyebilir.

Sosyal yardım hizmeti veren kamu kuruluşlarının sosyal yardım harcamaları tablo 5'de gösterilmektedir.Tabloda görüldügü üzere bu kamu kuruluşları; Aile, Çalışma ve Sosyal Hizmetler Bakanlığı(AÇSHB), Vakıflar Genel Müdürlüğü, Milli Eğitim Bakanlığı(MEB), Kredi ve Yurtlar Genel Müdürlügüu(YURT-KUR), Türkiye Kömür İşletmeleri Kurumu (TKİ), Türkiye Taşkömürü Kurumu(TTK) ve belediyelerdir. Türkiye genelinde hizmet veren Sosyal Hizmet Merkezlerinin sayısı Eylül 2020 itibarıyla 350'dir. 
Tablo 5. Sosyal Yardım Hizmeti Veren Kamu Kuruluşlarının Sosyal Yardım Harcamaları, 2018-2019

\begin{tabular}{|c|c|c|c|c|c|}
\hline \multirow[b]{2}{*}{ Kurum } & \multirow[b]{2}{*}{ Yardım Türü } & \multicolumn{2}{|c|}{2018} & \multicolumn{2}{|c|}{2019} \\
\hline & & $\begin{array}{l}\text { Yararlanic1 } \\
\text { Sayısı (1) }\end{array}$ & $\begin{array}{l}\text { Tutar } \\
\text { (Bin TL) }\end{array}$ & $\begin{array}{l}\text { Yararlanicı } \\
\text { Sayısı (1) }\end{array}$ & $\begin{array}{l}\text { Tutar } \\
\text { (Bin TL) }\end{array}$ \\
\hline \multirow{7}{*}{ 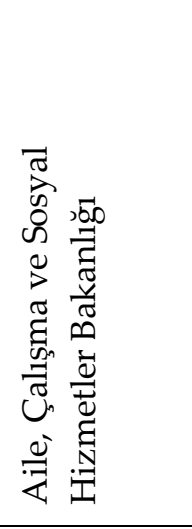 } & $\begin{array}{l}\text { Sosyal yardımlardan } \\
\text { faydalanan toplam hane sayısı }\end{array}$ & 3.494 .932 & & 3.282 .975 & \\
\hline & Yaşlı ve engelli aylığı (2022) & 1.412 .857 & 6.270 .340 & 1.510 .293 & 10.191 .0850 \\
\hline & $\begin{array}{l}\text { Sosyal ve ekonomik destek } \\
\text { (Çocukları muhtaç aileler) }\end{array}$ & 185.766 & 1.096 .121 & 198.907 & 1.389 .135 \\
\hline & Evde bakım & 513.276 & 6.675 .740 & 514.158 & 8.158 .669 \\
\hline & $\begin{array}{l}\text { SYDV'ler (Fon) tarafından } \\
\text { verilen tüm sosyal yardımlara } \\
\text { aktarılan kaynak }\end{array}$ & & 5.957 .458 & & 7.371 .671 \\
\hline & Genel sağlık sigortası primleri & 6.945 .909 & 8.973 .991 & 7.524 .138 & 12.118 .762 \\
\hline & Doğum yardımı (2) & 1.190 .053 & 506.489 & 1.120 .387 & 477.432 \\
\hline \multirow{3}{*}{ 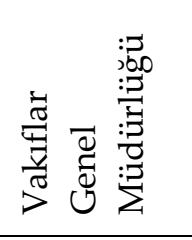 } & $\begin{array}{l}\text { Muhtaç aylığı (yetim ve } \\
\text { engelliler) }\end{array}$ & 4.869 & 36.279 & 4.956 & 44.241 \\
\hline & İmaret hizmetleri & 84.280 & 36.757 & 80.780 & 42.808 \\
\hline & $\begin{array}{l}\text { Burs (ilk ve ortaöğretimdeki } \\
\text { muhtaç öğrenciler) }\end{array}$ & 20.741 & 29.730 & 21.453 & 32.068 \\
\hline$\stackrel{9}{M^{1}}$ & $\begin{array}{l}\text { Burs (ilk ve ortaöğretimdeki } \\
\text { muhtaç öğrenciler) }\end{array}$ & 386.413 & 665.572 & 147.166 & 472.765 \\
\hline 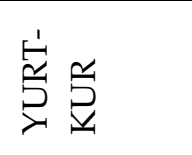 & $\begin{array}{l}\text { Burs (yükseköğretimdeki } \\
\text { muhtaç öğrenciler)(3) }\end{array}$ & 557.475 & 2.253 .784 & 569.747 & 2.401 .727 \\
\hline 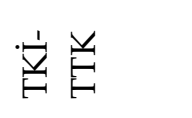 & Kömür yardımı & 2.084 .746 & 1.435 .809 & 1.878 .413 & 980.180 \\
\hline Belediyeler & Tüm sosyal yardımlar & - & 4.821 .827 & - & 7.141.703 \\
\hline Toplam & & & 38.253 .405 & & 50.174 .949 \\
\hline $\begin{array}{l}\text { Toplam/ } \\
\text { GSYİH (\%) }\end{array}$ & & & 1,02 & & 1,16 \\
\hline
\end{tabular}

Kaynak: SBB, 2021b, s.317.

(1) SYDV'ler (Fon) tarafından verilen tüm sosyal yardımlar ile kömür yardımında yararlanıcı sayısı hane sayısını, diğer yardım programlarında ise kişi sayısını ifade etmektedir.

(2) Doğum yardımında yararlanıcı sayısı çocuk sayısını ifade etmektedir.

(3) Üniversitelerin öğrencilerine verdikleri yardımlar bu rakama dahil değ ildir.

Tablo 5'de, sosyal yardım hizmeti veren kamu kuruluşlarının sosyal yardım harcamaları 2018 ve 2019 yılları itibariyle verilmiştir. 2019 yılındaki sosyal yardım harcamaları incelendiğinde, AÇSHB tarafından genel sağlık sigortası primleri türünde yapılan sosyal harcamaların 12.118.762.000 TL'lik tutarıla en büyük paya sahip olduğu görülmektedir. Daha sonra 10.191.0850.000 TL tutarıyla yaşlı ve engelli aylığı takip eder. 2019 yılında Türkiye'de sosyal 
yardım hizmeti veren kamu kuruluşlarının sosyal yardım harcamalarının toplamının GSYİH'ya oranı \%1,16 olmuştur (SBB, 2021b,s.317-318).

Sosyal koruma harcamaları bireylerin yaşam kalitelerini arttırmaya yönelik harcamalardır. Ülke içinde gelir dağılımının iyileştirilmesi ve yoksulluğun azaltılması ve toplum içinde birtakım sebeplere bağlı olarak dezavantajlı olan grupları koruma altında alınması gayesini güder. Gelir eşitsizliğini ölçmede dünya genelinde en temel gösterge olarak gini katsayısı kullanılmaktadır. Gini katsayısı ülkelerin gelir dağılımındaki iyileşmelerinin veya kötüleşmelerini izlenebilmesi açısından önemli bir araçtır. Türkiye'de 2009 yılında 0,415 olarak hesaplanan gini katsayısı, 2019 yılında 0,395'e gerilemiştir. Türkiye' de en zengin yüzde $20^{\prime}$ lik grubun yıllık kullanılabilir gelirden aldığ 1 payın en yoksul yüzde 20 'lik grubun aldığ 1 paya oranı 2009 yılında 8,5 iken 2019 yilında 7,4'e gerilemiştir (SBB, 2021b,s.315). Bu durum Türkiye için olumlu gelişmeler olarak değerlendirilebilir.

\section{Türkiye'de Sosyal Koruma Harcamaları Kapsamında Yaşlılara Yönelik Harcamalar}

Yaşlılar için sosyal koruma temelde yaşlı bireylerin şu anki ve sonrası yaşamları için hak, haysiyet ve gelir güvenliğinin sağlanmasını kapsamaktadır. İnsan hakları belgelerinde ve uluslararası çalışma standartlarında dayandırıldığı üzere, bireylerin yaşlılıkta gelir güvencesi hakkı, yeterli bir sosyal güvenlik ve emekli maaşı hakları mevcuttur (ILO, 2014,s.xiii). Bu bağlamda yaşlılara yönelik sosyal koruma harcamaları, yaşlı bireylerin bu haklarını elde edebilmeleri ve koruyabilmeleri için yapılan harcamalardır.

Yaşlı bireyler için özellikle güvenilir gelir güvencesi kaynakları önemli bir husustur. Toplumdaki bireyler yaşlandıkça, çeşitli nedenlerle işgücü piyasasında elde ettikleri gelire daha az güvenmeye başlarlar. Toplumdaki yüksek eğitimli profesyoneller çoğu zaman hayatlarının sonlarına kadar iyi ücretli mesleklerini icra edebilirken, maalesef nüfusun çoğunluğunun genellikle yaşları ilerledikçe iyi ücretli işlere erişimden dışlandığ görülmektedir. Elbette bireylerin özel tasarrufları ve konut gibi mal varlıkları kişisel durumlarını değiştirir, ancak bireylerin özel tasarrufları ve mal varlıkları birçok insan için genellikle hayatlarının sonuna kadar makul düzeyde bir gelir güvencesi sağlamak için yeterli olmamaktadır. Aile yapısına bağlı olarak aile içi transferler, ek bir gelir güvencesi kaynağ olarak görülebilir. Ancak bu çalışmanın önceki bölümünde bahsedildiği üzere, günümüz dünyasında aile yapısında bir dönüşüm yaşanmakta olup, yaşlı bireylerinde içinde yer aldığı geleneksel aile yapısından uzaklaşılmış; aileler boyut, karakter olarak daha heterojen ve karmaşık bir hale gelmiştir. Bu yeni yapıda yaşlı bireylere yapılacak aile içi transferler kaygı verici bir belirsizliktedir. Ayrıca aile içi transferlerle yaşlı bireylere ek gelir güvencesi sağlanabilse bile, bu güvence çoğu zaman özellikle düşük gelirli ailelerce yeterli düzeyde olmayabilir (ILO, 2014,s.1).

Dünya genelinde olduğu gibi Türkiye'de de artan yaşlı nüfusun ihtiyaçlarını ve taleplerini karşılamaya yönelik sosyal hizmetlerin ağırlığı giderek artmaktadır. Bu alandaki sosyal hizmetlerin genişletilmesi ve kalitesinin artırılması hükümetlerce AÇSHB'ye bağlı olarak yürütülmektedir. Tablo 6, AÇSHB'ye bağlı sosyal hizmet kuruluşlarının sayı ve kapasitelerini göstermektedir. AÇSHB'ye bağlı huzurevi sayısı ve kapasitesi 2002 yılına göre yaklaşık 2,4 kat artmıştır.Türkiye' de AÇSHB'ye bağlı huzurevi sayısı Eylül 2020 itibarıyla 156'ya ulaşmıştır. Ayrıca yerel yönetimlerde bu süreçte önemli roller üstlenmekte yerel yönetimler bünyesinde 
oluşturulan Yaşlı Destek Programı (YADES) ile proje bazlı destek sağlanmaktadır. YADES kapsamında 2020 yılı için 2.952.000 TL kaynak ayrılmıştır (SBB, 2021b,s.318).

Tablo 6. Aile, Çalışma ve Sosyal Hizmetler Bakanlığına Bağlı Sosyal Hizmet Kuruluşlarının Sayı ve Kapasiteleri

\begin{tabular}{lcccccccc}
\hline Kuruluş Türleri & \multicolumn{2}{c}{$\mathbf{2 0 1 7}$} & \multicolumn{2}{c}{$\mathbf{2 0 1 8}$} & \multicolumn{2}{c}{$\mathbf{2 0 1 9}$} & \multicolumn{2}{c}{ 2020(1) } \\
& Sayı & Kapasite & Sayı & Kapasite & Sayı & Kapasite & Sayı & Kapasite \\
\hline Çocuk Evi (0-18 yaş) (2) & 1189 & 6830 & 1192 & 6786 & 1192 & 6853 & 1192 & 6841 \\
Çocuk Evleri Sitesi (Sevgi & 106 & 6878 & 111 & 7047 & 112 & 7097 & 111 & 7097 \\
Evleri) & & & & & & & & \\
Çocuk Destek Merkezleri (3) & 65 & 1962 & 63 & 2011 & 65 & 2147 & 65 & 2137 \\
Huzurevi & 144 & 14793 & 146 & 14967 & 152 & 15258 & 156 & 15841 \\
Engelli Bakım ve & 239 & 8674 & 250 & 7869 & 258 & 8008 & 381 & 8929 \\
Rehabilitasyon Merkezi (4) & & & & & & & & \\
Sosyal Hizmet Merkezi & 260 & - & 319 & - & 333 & - & 349 & - \\
$\begin{array}{l}\text { Kadın Konuk Evi ve İlk } \\
\text { Kabul Birimi }\end{array}$ & 102 & 2667 & 110 & 2697 & 110 & 2717 & 110 & 2717 \\
ŞÖNiM(Şiddet Önleme ve & 68 & - & 79 & - & 81 & - & 81 & - \\
İzleme Merkezi) & & & & & & & & \\
\hline
\end{tabular}

Kaynak: SBB, 2021b, s.318.

(1) Eylül 2020 itibarıyla

(2) Çocuk evleri müstakil apartman dairelerinden ibarettir.

(3) Bakım ve Sosyal Rehabilitasyon Merkezleri ile Koruma Bakım ve Rehabilitasyon Merkezleri Çocuk

Destek Merkezleri Yönetmeliğiyle Çocuk Destek Merkezine dönüştürülmüştür.

(4) Yatılı engelli bakım ve rehabilitasyon merkezileri, umutevleri ve gündüzlü bakım kuruluşların toplamidir.

Türkiye'de toplam nüfus içindeki oranı giderek artan yaşlı nüfusa yönelik hizmet alanlarının genişletilmesi ve kalitesinin artırılmasına yönelik çalışmalar devam etmektedir. Bu kapsamda politikalar belirlenerek gerekli tedbirler alınmaktadır.Tablo 7' de 2017-2019 yılları için sosyal hizmet harcamalarının harcama yapılan kesime göre dağılımı gösterilmiştir. Harcama yapılan kesim "çocuk-genç", "yaşlı", "engelli", “toplum-aile-kadın” olmak üzere dört gruba ayrılmıştır.

Tablo 7. Sosyal Hizmet Harcamalarının Harcama Yapılan Kesime Göre Dağılımı

\begin{tabular}{|c|c|c|c|c|c|}
\hline \multicolumn{2}{|c|}{ Harcama Yapılan Kesim } & Kuruluş & 2017 & 2018 & 2019 \\
\hline \multicolumn{2}{|c|}{ Çocuk-Genç } & AÇSHB & 1.623 .381 & 2.432 .161 & 2.878 .199 \\
\hline \multicolumn{2}{|l|}{ Yaşlı } & AÇSHB & 611.469 & 757.225 & 898.170 \\
\hline \multirow{3}{*}{ Engelli } & Kurum Bakımı & AÇSHB & 491.898 & 702.822 & 629.553 \\
\hline & Özel Kuruluşta Bakım & AÇSHB & 391.573 & 544.342 & 728.564 \\
\hline & Özel Eğitim & MEB & 2.418 .795 & 2.747.316 & 2.239 .754 \\
\hline \multicolumn{2}{|c|}{ Toplum-Aile-Kadın } & AÇSHB & 375.974 & 353.411 & 324.182 \\
\hline \multicolumn{2}{|l|}{ Toplam } & & 5.913 .090 & 7.537 .277 & 8.838 .527 \\
\hline
\end{tabular}

Kaynak: SBB, 2021b, s.319. 
Türkiye'de yaşlılara yönelik politika öncelikleri arasında toplum temelli bakım hizmetleri kapsamında gündüzlü bakım hizmetlerinin yaygınlaştırılması gelmektedir. Bu kapsamda sorumlu kuruluş olarak AÇSHB ilgili kamu kurum ve kuruluşları, yerel yönetimler ve Sivil Toplum Kuruluşları (STK) ile işbirliği içinde çalışmaktadır. Gündüzlü bakım hizmetlerinin yaygınlaştırılmasına yönelik mevzuat çalışmasının kısa vadede tamamlanması öngörülmüştür. Uzun süreli bakıma ihtiyaç duyan yaşlılar için hizmetlerin çeşitlendirilmesi ve yaygınlaştırılmasına yönelik politikalar oluşturulmaktadır. Farklı kurumlarca sunulan uzun vadeli evde bakım hizmetlerinin bir bütünlük içinde, kurumlar arası eşgüdümle yürütülmesi ve bu süreçte yerel yönetimlerin daha fazla rol almasına imkan verecek düzenlemelerin yapılması öngörülmüştür. Yaşlı bireylerin hayat boyu öğrenme imkanlarına erişimi kolaylaştırılmasına yönelik tedbirler alınmaktadır. Tedbirler kapsamında Türkiye' de yaşlılara yönelik dijital okur-yazarlık ve finansal okuryazarlık kursları verilecek, Milli Eğitim Bakanlığı eğitim programlarının yaşlılara uyarlanması sağlanacaktır (SBB, 2021b,s.322-342).

Yaşlı nüfusun iş gücüne katılım oranı 2018 yılı için \%12,5 olarak hesaplanmıştır. Bu oranın arttırılması amacıyla yaşlıların belirli şartlarda çalışma hayatında kalabilmesini sağlayacak mekanizmalar geliştirilmesi 2021 yılı Cumhurbaşkanlığı yıllık programında öngörülmüştür (SBB, 2021b,s.342). Ayrıca yine kalkınma planı kapsamında, evde sağlık hizmetlerinin yaygınlaştırılması ve özellikle kırsal alanda yaşayan yaşlılara sunulan sağlık hizmetlerine erişiminin kolaylaştırılması, yaşlılara yönelik koruyucu ve tedavi edici hizmetlerin güçlendirilmesi hedeflenmektedir (SBB, 2021b,s.288).

Çalışmanın ilk bölümünde de ifade edildiği üzere sosyal harcamalar sınırlarının zor çizildiği, temelde bireylerinin refahını arttırmak amacını güden, ancak çeşitli şekillerde gruplanabilen, farklı kurum ve kuruluşlarca gerçekleştirilebilen bu bağlamda finansman kaynaklarının çeşitlilik gösterdiği harcamalardır. Sosyal harcamalar sadece kamu kesimince yapılmamakta STK ve toplumdaki bireylerinde bu harcamalar içinde payı bulunabilmektedir. Farklı kurumlarca farkı kaynakların baz alınmasına bağlı olarak sonuçlarda değişiklik göstermektedir. Örneğin ESSPROS ve SOCX metodolojisinde eğitim harcamaları dahil edilmezsen ILO'in metodolojisine dahil edilmesi, hesaplanan değerlerde ciddi farklılıklar doğurur. Çalışmanın daha kapsamlı olabilmesi adına uluslararası bir karşılaştırma yapmak çalışmaya anlam katacaktır. Bu bağlamda bir sonraki başlıkta Türkiye'de ve AB'de yaşlılara yönelik sosyal harcamalar incelenmiştir.

\section{Yaşlılara Yönelik Sosyal Harcamalar: Türkiye ve AB}

Yaşlılara yönelik sosyal harcamalar, yaşlılar için sosyal güvenlik ve insan haklarının kullanılabilmesinde, gelir güvenliğinin sağlanmasında, sağlık ve bakım hizmetlerini de kapsayacak şekilde temel hizmetlere kendi haklarını ve onurlarını artıracak şekilde erişimlerinin sağlanmasında önemli bir rol oynamaktadır (ILO, 2014,s.1). Bu bölümde Türkiye ve $A B$ ülkelerinde sosyal koruma harcamaları kapsamında yaşlılara yönelik sosyal harcama verileri Avrupa Birliği'nin ESSPROS sistemine başvurularak incelenmiştir.

Grafik 5'de 2008-2018 yılları arasında AB ülkeleri ve Türkiye'de sosyal harcamalarının GSYİH'den aldıkları pay gösterilmektedir. 2018 yılında AB ortalaması \%27,9 iken Türkiye'de sosyal harcamalarının GSYİH'den aldığ pay \%11,9 olmuştur. Türkiye'nin sahip olduğu bu 
oran, $\mathrm{AB}$ ortalamasının oldukça altındadır. $\mathrm{AB}$ üye ülkeleri arasında en düşük orana sahip olan ülke \%14,2 ile İrlanda'dır. Türkiye'deki oran bunun da altındadır.

Grafik 5. Kamu Sosyal Harcamalarl, GSYİH (\%), 2008-2018

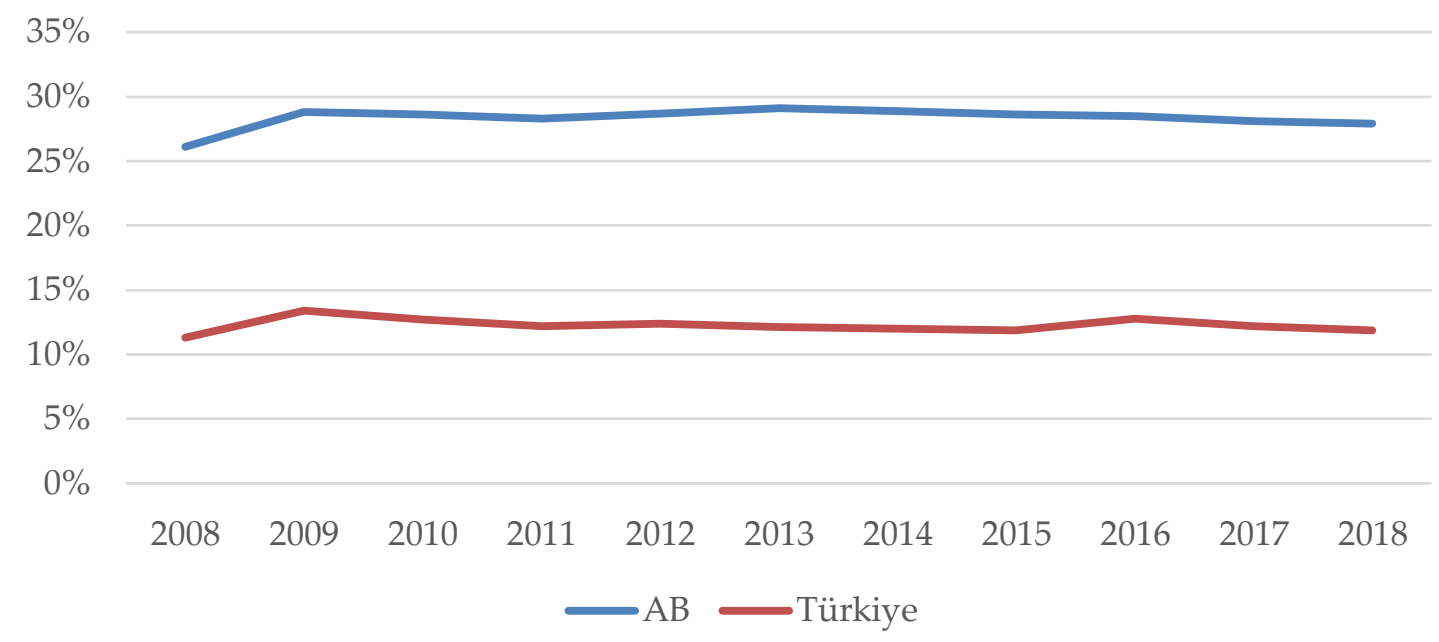

Kaynak: Eurostat, 2021b.

2018 yılında AB üye ülkeleri içinde sosyal harcamalarının GSYİH içindeki payının en yüksek olduğu ülke \%31,8 oranı ile Danimarka'dır. En yüksek oran sıralamasında Danimarka'yı, Finlandiya(\%30,1), Almanya(\%29,6) ve Avusturya(\%29,2) takip etmektedir. 2018 yılinda sosyal harcamalarının GSYİH içindeki payının en düşük olduğu ülke \%14,2 oranıyla İrlanda'dır. 2008 yılında İrlanda'da sosyal harcamalarının GSYİH içindeki payı \%20,9 iken, 10 yıllık bir süre zarfında bu pay ciddi oranda azalmıştır. Eurostat'ın İrlanda için yayınladığı en güncel veri 2019 yılına ait olup, ilgili yılda İrlanda' da sosyal harcamalarının GSYİH içindeki payı \%13,6 olarak hesaplanmıştır. Bu bağlamda İrlanda'da sosyal harcamalarının GSYİH içindeki payının azalma eğiliminin devam etmekte olduğu görülmektedir. Romanya(\%15), Letonya(\%15,2), Malta(\%15,4) ve Litvanya(\%15,8) 2018 yılına ait verileri olan ülkeler arasında en düşük paya sahip diğer ülkelerdir(Eurostat, 2021b).

10 yıllık süre zarfında $A B^{\prime}$ de ve Türkiye'de sosyal harcamalar oransal olarak büyük bir değişime uğramamıştır. 2008 yılında $\mathrm{AB}$ ortalaması \%26,1 iken 2018 yılında \% 27,9 olmuştur. Türkiye'de 2008 yılında \%11,3 olan bu oran, 2018 yılında \%11,9'a ulaşmıştır. AB'de 10 yıllık süre zarfında $\% 1,8^{\prime}$ lik bir artış yaşanırken Türkiye' de aynı süre zarfı içinde $\% 0,6^{\prime}$ lık bir artış yaşanmıştır. 
Grafik 6. AB'de Sosyal Koruma Harcamalarının Dağılımı, 2018

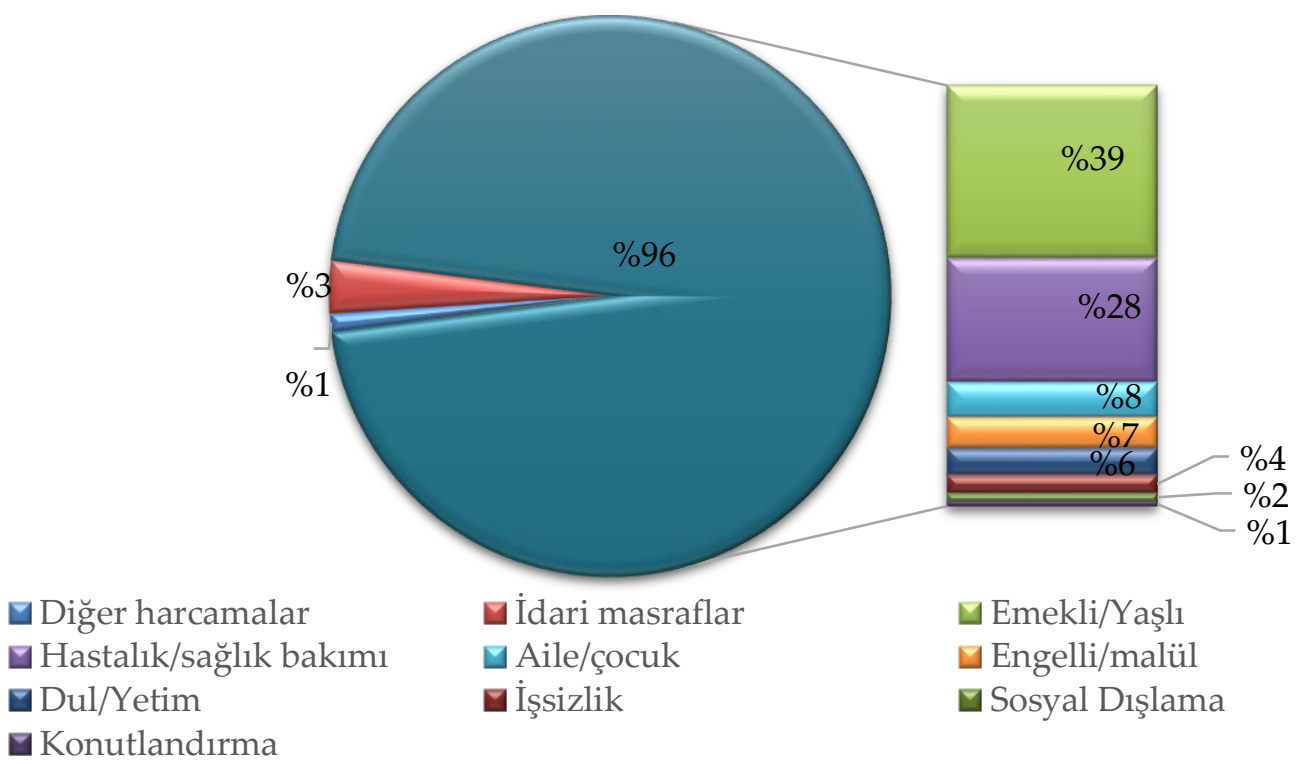

Kaynak: Eurostat, 2021b.

Grafik 6, 2018 yılında AB'de sosyal koruma harcamaların dağılımını göstermektedir. Dağılım içinde idari masraflar \%3, diğer harcamalar ise \%1'lik küçük bir paya sahiptir. Bunları dışındaki \%96'lık kısım sosyal koruma yardımları olarak değerlendirilmektedir. Toplam dağılım için \%39 değeriyle emekli ve yaşlılara yönelik harcamalar en önemli paya sahiptir. Sonrasında hastalık ve sağlık bakımı \%28'lik payla önemli yer tutmaktadır. Dağılımda sırasıyla, aile ve çocuk $\% 8$, engelli/malül \%7, dul/yetim $\% 6$, işsizlik $\% 4$, sosyal dışlanma $\% 2$ ve konutlandırma \%1'lik paya sahiptir (Eurostat, 2021b).

Grafik 7. Sosyal Harcamalarının Dağılımı, GSYİH (\%), 2018

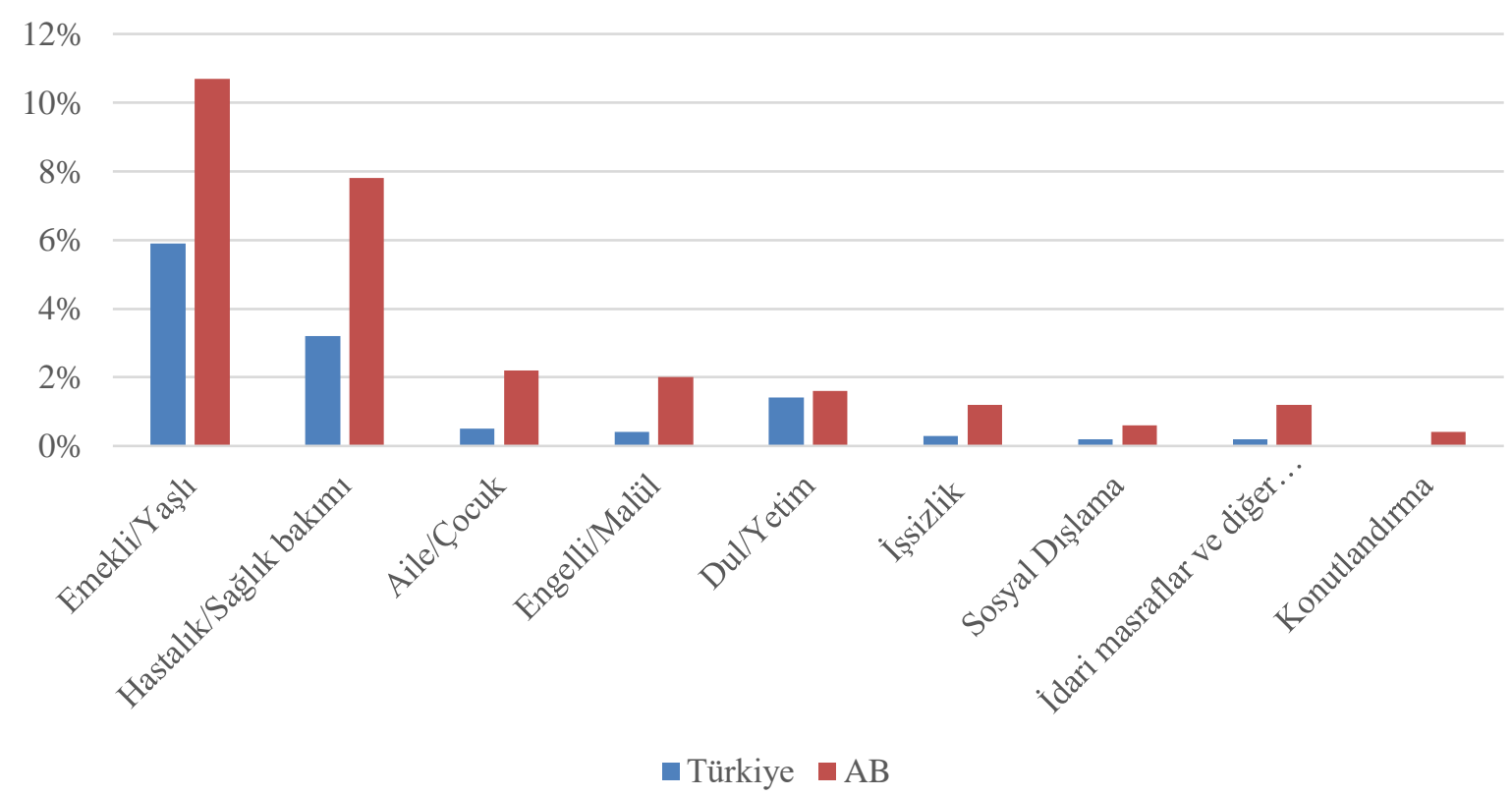

Kaynak: Eurostat, 2021b. 
Grafik 7'de, 2018 yılında AB ve Türkiye'deki sosyal harcama bileşenlerinin dağılımı gösterilmektedir. 2018 yılı, karşılaştırma yapabilmek adına AB ortalamasına ilişkin en güncel ve eksiksiz verilerin mevcut olduğu yıl olması sebebiyle seçilmiştir. Grafik sosyal harcama bileşenlerinin GSYİH içindeki paylarının dağılımını göstermektedir. Hem AB ülkeleri genelinde hem de Türkiye'de GSYİH'den en çok pay alan sosyal harcama türü, emekli/yaşlılara yönelik harcamalardır. AB ülkelerinde emekli/yaşlılara yapılan kamu harcamalarının payı \%10,7'dir.Aynı yıl Türkiye'de emekli/yaşlılara yapılan kamu harcamalarının payı ise $\% 5,9^{\prime}$ dur. Hem $\mathrm{AB}^{\prime}$ nin hem de Türkiye' nin önemle üzerinde durduğu sosyal koruma harcamalarının yaşlılara yönelik olduğu görülmektedir. Bu harcamaların önemli bir bölümünü emekli maaşları ödemeleri oluşturmaktadır (Eurostat, 2021b).

Türkiye'de GSYİH içindeki sosyal harcamaların hem toplam payı $(\% 11,9)$ hem de bileşenlerinin her birinin aldığı paylar $\mathrm{AB}$ ortalamasının oldukça altındadır. AB'de yaşlılara yönelik sosyal harcamalardan sonra en büyük paya sahip olan harcama $\% 7,8^{\prime}$ lik payiyla hastalık ve sağlık bakımına yönelik olmuştur. Türkiye'de hastalık/sağlık bakımına yönelik yapılan harcamalar ise \%3,2' dir. Diğer sosyal harcama türleri ise dağılımda oldukça küçük paylara sahiptir. Aile ve çocuklara yönelik harcamalar $A B$ için \%2,2 oranında olurken, Türkiye' de $\% 0,5^{\prime}$ dir. Engelli ve malullere yönelik harcamalar $\mathrm{AB}^{\prime} \mathrm{de} \% 22^{\prime}$ lik bir paya sahipken, Türkiye'de \%0,4 oranında kalmıştır. İşsizliğe yönelik sosyal harcamaların payı AB için \%1,2 olurken, Türkiye'de \%0,3'tür. Sosyal dışlanma sorununa yönelik harcamalar AB'nde \%0,6 olurken, Türkiye'de \%0,2'dir. Konutlandırmaya yönelik Türkiye'de bir sosyal harcama yapılmamışken, $\mathrm{AB}^{\prime}$ de bu oran \%0,4'tür (Eurostat, 2021b).

Grafik 8. Yaşlılara Yönelik Sosyal Harcamalar, GSYİH (\%), 2008-2018

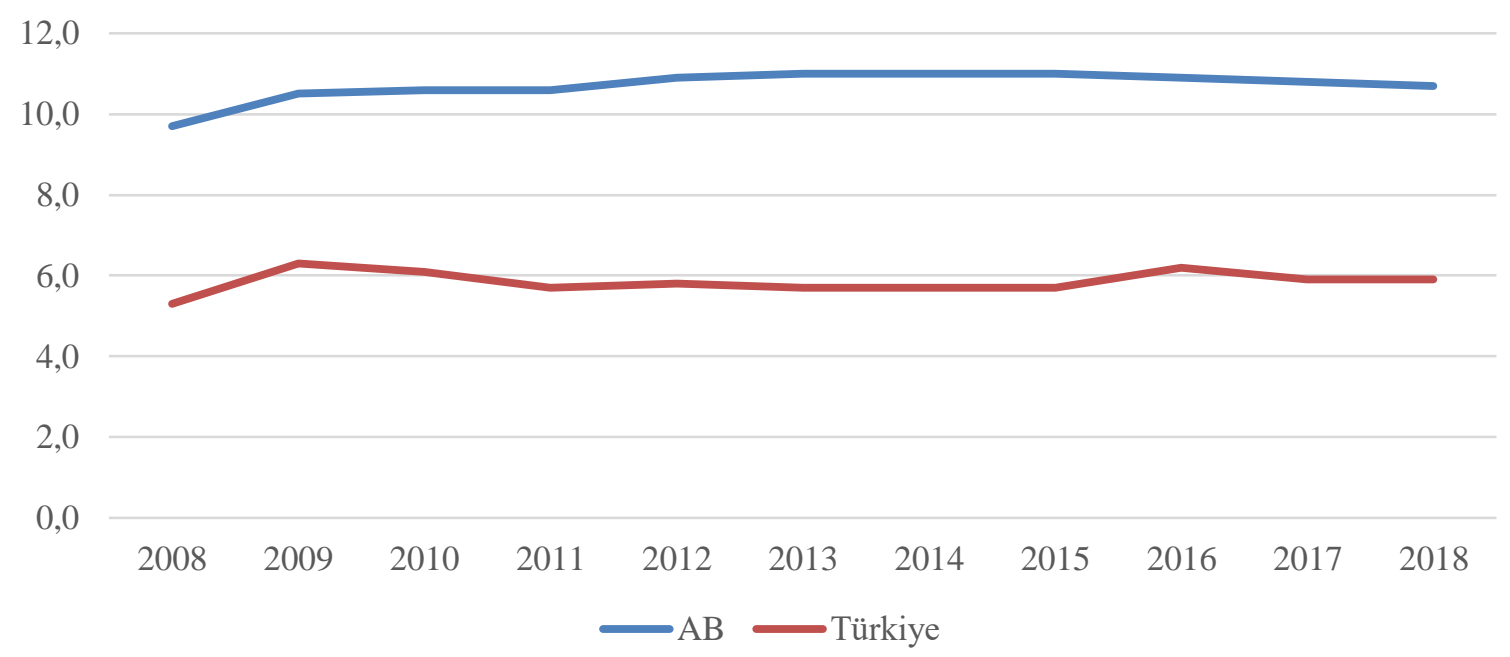

Kaynak: Eurostat,2021b.

Grafik 8'de 2008-2018 yılları arasında Türkiye'de ve AB'de yaşlılara yönelik yapılan sosyal harcamaların GSYİH' den aldıkları paylar gösterilmektedir. İlgili dönem boyunca Türkiye'deki oran AB ortalamasının altında kalmıştır.2008 yılında Türkiye' de oran \%5,3 iken 2018' de \%5,9'a çıkmıştır. AB ortalaması 2008 yılında \%9,7 iken 2018 yılında \%10,7’ye yükselmiştir. 
Türkiye'de sosyal harcamaların en çok yaşlılara yönelik yapıldığ1 görülmektedir. Ancak Türkiye'de yaşlılara yönelik yapılan sosyal harcamaların oranı AB ortalamasının oldukça altındadır. Tablo 8' de 2018 yılında AB üyesi ülkelerde ve Türkiye'de yaşlılara yönelik sosyal harcamaların GSYİH içindeki payları gösterilmektedir. Tablodaki sıralama, en büyük paya sahip olan ülkeden en düşük paya sahip olan ülkeye doğrudur.İtalya \%13,7 ve Yunanistan $\% 13,6$ 'lık oranıyla sıralamanın başında yer almaktadır. Türkiye'de yaşlılara yönelik sosyal harcamaların GSYİH'den aldığı pay, AB ülkeleri arasında İrlanda $(\% 4,3)$ dışındaki tüm üye ülkelerin sahip olduğu paydan düşüktür.

Tablo 8. Yaşlılara Yönelik Sosyal Harcamaların GSYİH içindeki Payları: Türkiye, AB

\begin{tabular}{|c|c|}
\hline & 2018 \\
\hline AB-27 & $\% 10,7$ \\
\hline İtalya & $\% 13,7$ \\
\hline Yunanistan & $\% 13,6$ \\
\hline Fransa & $\% 12,7$ \\
\hline Avusturya & $\% 12,7$ \\
\hline Finlandiya & $\% 12,7$ \\
\hline Danimarka & $\% 12,2$ \\
\hline İsveç & $\% 12,2$ \\
\hline Portekiz & $\% 11,6$ \\
\hline Belçika & $\% 11,0$ \\
\hline Hollanda & $\% 10,3$ \\
\hline İspanya & $\% 9,8$ \\
\hline Almanya & $\% 9,2$ \\
\hline Polonya & $\% 9,1$ \\
\hline \begin{tabular}{|l|} 
Slovenya \\
\end{tabular} & $\% 9,0$ \\
\hline GKRY & $\% 8,5$ \\
\hline Çekya & $\% 7,8$ \\
\hline Macaristan & $\% 7,6$ \\
\hline Hirvatistan & $\% 7,2$ \\
\hline Romanya & $\% 7,2$ \\
\hline Bulgaristan & $\% 7,1$ \\
\hline Slovakya & $\% 7,1$ \\
\hline Letonya & $\% 7,0$ \\
\hline Lüksemburg & $\% 6,9$ \\
\hline Malta & $\% 6,6$ \\
\hline Estonya & $\% 6,5$ \\
\hline Litvanya & $\% 6,4$ \\
\hline İrlanda & $\% 4,3$ \\
\hline Türkiye & $\% 5,9$ \\
\hline
\end{tabular}

Kaynak: Eurostat, 2021b. 
Grafik 9'da Türkiye ve AB'de türlerine göre sosyal koruma gelirlerinin 2018 yılındaki dağılımı gösterilmektedir. Sosyal koruma gelirlerinin büyük bir kısmı genel devlet katkısıyla sağlanmaktadır. 2018 yılında, AB için \%38 olan genel devlet katkısı, Türkiye için \%40,21 olmuştur. Sıralamada daha sonra AB'de \%36 oranla işveren sosyal katkısı gelirken, Türkiye' de işveren sosyal katkısı \%27,91 olmuştur.Koruma kapsamındaki bireyler tarafından yapılan sosyal katkı AB'de \%22 olurken, Türkiye'de \%23,60 olmuştur. Son olarak $\mathrm{AB}^{\prime}$ de $\% 4$ oranında diğer gelirler mevcutken, Türkiye'de diğer gelirlerin oranı $\% 8,26$ 'dır. Grafikte görüldüğü üzere hem $\mathrm{AB}$ hem Türkiye'de sosyal koruma harcamalarının finansmanında genel devlet katkısı büyüktür. Bu durum ülkelerin sosyal devlet olma ilkeleriyle örtüşmektedir.

Grafik 9. Türlerine Göre Sosyal Koruma Gelirlerinin Dağılımı: Türkiye, AB, 2018

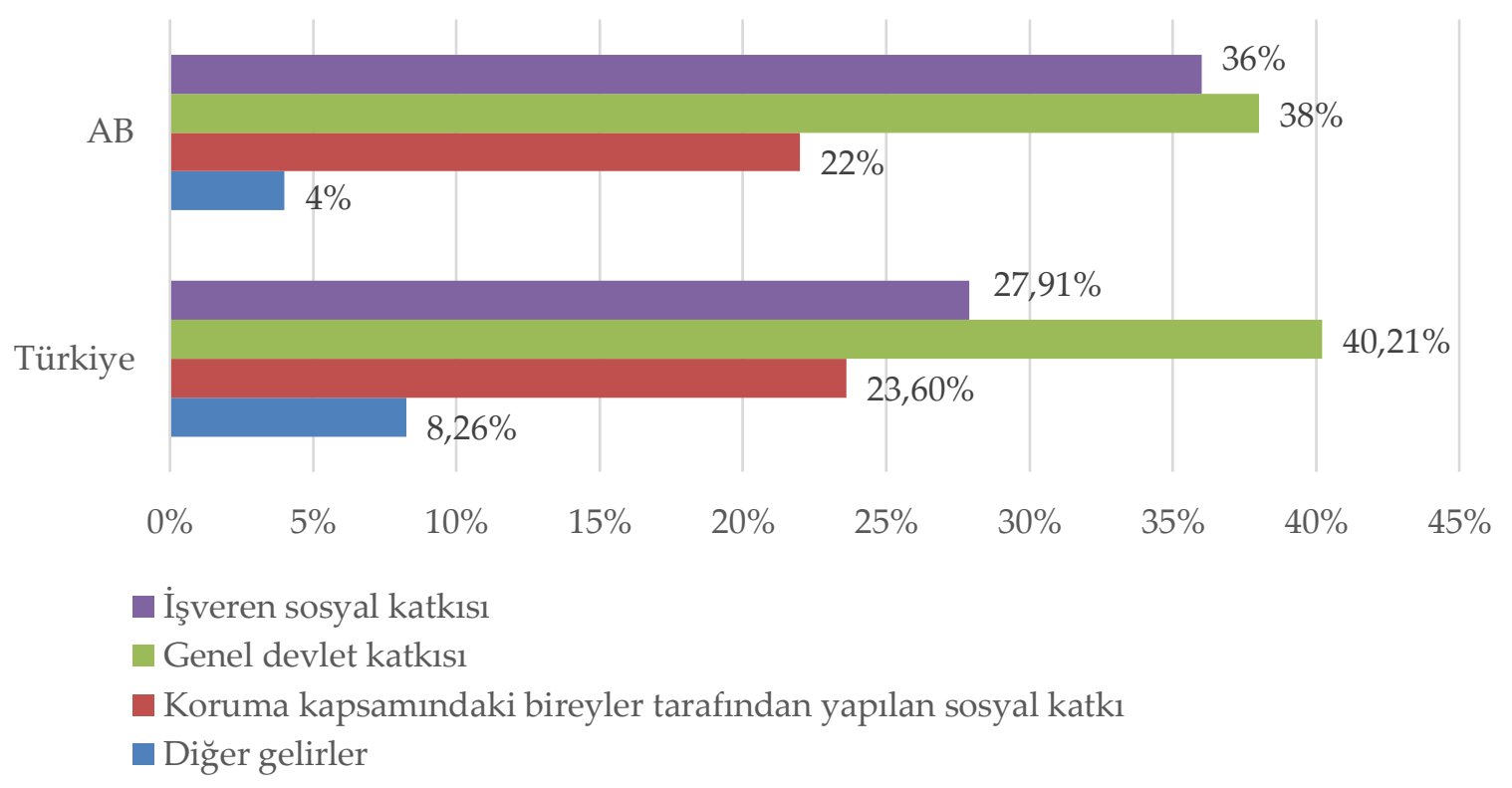

Kaynak: Eurostat, 2021b.

\section{Sonuç}

Günümüzde nüfus giderek yaşlanmakta olup küresel etkiler yaratmaktadır. Bu durum gelişmiş ülkeler ile gelişmekte olan ülkeler arasında farklı etkiler yaratabiliyor olsa da, genel anlamda ülkelerin yaşlılara yönelik sosyal politikalarını geliştirmeleri sonucunu doğurmaktadır. Yaşlı nüfusun artması, yaşlılara yönelik kamu harcamalarının ülkelerin sosyal harcamaları içindeki payını daha da artırmaktadır. Bu alandaki sosyal harcamalar yaşlı nüfusun ihtiyaçları ve çağın koşullarına uygun taleplerini karşılamak amacıyla yapılmaktadır. Yaşlılara yönelik kamu sosyal harcamalarının büyük bir çoğunluğunu ise emekli maaşları ve yaşlılık aylıkları gibi sosyal güvenlik hizmetleri kapsamındaki kamu harcamaları oluşturmaktadır.

Yoksullukla mücadele, gelir dağılımında adaletin sağlanması gibi toplum refahının arttırılması ve/veya engelliler, çocuklar ya da yaşlılar gibi bazı açılardan dezavantajlı olarak kabul edilebilen grupların koruma altında alınması amaçlarını güden "sosyal bütçeleme" devletin önemli bir aracını oluşturmaktadır. Farklı sosyal harcamaların ön planda tutulmasıyla sosyal bütçe çeşitli türlere ayrılabilmektedir. Bütçede yaşlılara yönelik ihtiyaçlara 
ağırlık verilerek, yaşlı haklarının korunması, yaşlı sosyal refahının arttırılması, aktif yaşlanma sürecinin desteklenmesi hedeflenebilir. Yaşlılara yönelik yürütülen sosyal politikaları merkeze alan tür esaslı bir bütçeleme kamu bütçesinde yeni yaklaşımlar kapsamında değerlendirilebilir. Çünkü artan yaşlı nüfusla beraber yaşlı nüfusun sosyal ihtiyaçları ve devlet bütçesinde yaşlılara yönelik sosyal koruma harcamalarının payı gün geçtikçe artmaktadır. Bu bağlamda sadece Türkiye' nin nüfusu yaşlanmamakta, dünya nüfusu küresel yaşlanma süreci içine girmiş bulunmaktadır. Bu süreç demografik değişimi de kapsamakta olup ülkelerin politikalarını bu durumu gözüne alarak şekillendirmelerini gerektirmektedir. Artan yaşlı nüfus özellikle artan sosyal güvenlik hizmetlerini beraberinde getirmektedir. Nüfusun yaşlanmasıyla birlikte yaşlı bağımlılık oranı artmaktadır. Bu alanda yaşlı nüfusun istihdam içindeki payını arttırıcı sosyal politika uygulamaları hem yaşlıların aktif yaşlanma sürecine dahil olabilmelerine hem de içinde bulunulan bu demografik dönüşümde yaşlıların toplum üzerinde bir maliyet yükü oluşturduğu algısını değiştirebilir.

Türkiye'de sosyal harcamaların AB ülkelerinde yapılan sosyal harcamalar düzeyinin oldukça altında olduğu görülmektedir. Türkiye' de yaşlılara yönelik sosyal harcamalar, toplam sosyal harcamalar içinde en büyük paya sahiptir. Ancak yaşlılara yönelik sosyal harcamalar da AB ülkeleri ortalamasının bir hayli altında kalmaktadır. Türkiye' de bir sosyal politika alanı olarak yaşlılara yönelik harcamalar önemli bir paya sahip olsa da GSYİH içindeki payının oldukça düşük olması yaşlı sosyal refahının çok yüksek olmadığını göstermektedir. Bu bağlamda Türkiye'de yaşlı sosyal refahını yükseltmeye yönelik politika önerileri şu şekilde sıralanabilir

- Merkezi hükümetin yanında yerel yönetimlerin rolü arttırılmaya çalışılabilir. Bu amaçla sosyal bütçe kullanılabilir. Sosyal bütçeleme merkezi yönetim düzeyinde mümkün olmakla beraber, halka en yakın hizmet birimi olması sebebiyle yerel yönetimlerin bu konudaki çalışmaları daha etkin netice verebilir. Günümüzde hızla gelişmekte olan sosyal belediyecilik anlayışı merkeze alınarak, ülkemizde yaşlı dostu şehirlerin kurulmasına ağırlık verilebilir. Yerel yönetimler bünyesinde oluşturulan projelerle yaşlıların işgücü piyasasına katılımları sağlanabilir.

- Yaşlanmanın kamusal bir maliyeti olduğu bilinen bir gerçektir. Söz konusu maliyet yaşlıların iş piyasasına katılımlarının arttırılmasıyla düşürülebilir. Çalışma ortamının tüm nesillerin ihitiyaçlarına göre uyarlandığı, yaşam boyu öğrenme, esnek emeklilik gibi programların mevcut olduğu nesiller arası dayanışmayı geliştiren düzenlemelerle aktif yaşlanma stratejilerine ağırlık verilebilir.

- Yaşlanmanın kamusal maliyetlerini azaltmak için evde bakım ve sağlık hizmetleri hem gelişmiş ülkelerde hem de Türkiye'de sunulmaya başlanmıştır. Bu hizmetlerin yaygınlaşması maliyetlerin düşmesi açısından oldukça önemlidir.

- Yaşlılığı toplumsal bir sorun olarak görmek yerine, uzayan yaşam süresinin özellikle teknolojik gelişme yoluyla ekonomik büyüme için fırsata çevirilmesi hedeflenebilir.

Bugünün gençlerinin yarının yaşlıları olacağı gerçeğinden yola çıkarak, yaşlıların yaşam kalitesinin arttırılmasının faydaları zamanla tüm topluma yayılacaktır. 


\section{Kaynakça}

Altuğ, F. (2020). Kamu Bütçesi, İstanbul: Beta Yayınevi.

Arısoy,İ., Ünlükaplan, İ., \&Ergen, Z. (2010). Sosyal Harcamalar ve İktisadi Büyüme İlişkisi: Türkiye Ekonomisinde 1960 - 2005 Dönemine Yönelik Bir Dinamik Analiz. Maliye Dergisi,158, 398-421.

Cengiz, İ. (2018). Türk Sosyal Güvenlik Sistemi İçerisinde Yaşlılara Yönelik Sosyal Yardım ve Sosyal Hizmetler. Journal of Social Security, 8(2), 23-40.

Doğan,A.\&Kabayel,M.(2017). Sosyal Güvenlik ve Sosyal Güvenlik Harcamaları Üzerine Değerlendirmeler. MCBÜ Sosyal Bilimler Dergisi, 15(2), 217-240.

Dökmen,G.,\&Kaplan,Z.(2018). Sosyal Harcamaların Devlet Borçlanması Üzerindeki Etkisi: OECD Ülkeleri Örneği. Maliye Araştırmaları Dergisi, 4(2), 99-113.

EC.(2016).ESSPROS Manual and User Guidelines. Luxembourg: Publications Office of EU. Erişim adresi: https://ec.europa.eu/eurostat/documents/3859598/7766647/KS-GQ-16-010EN-N.pdf/3fe2216e-13b0-4ba1-b84f-a7d5b091235f

EC.(2019).Manual on sources and methods for the compilation of COFOG statistics. Luxembourg: Publications Office of the European Union. Erişim adresi: https://ec.europa.eu/eurostat/documents/3859598/10142242/KS-GQ-19-010-EN-

N.pdf/ed64a194-81db-112b-074b-b7a9eb946c32?t=1569418084000

EC.(2021).Ageing Policy. Erişim adresi: https://ec.europa.eu/employment_social/socprot/ageing/intro_en.htm

Erdoğdu,M.,\&Yenigün, E. (2008). Türkiye'de Sosyal Bütçe-Nasıl Yapılıyor? Nasıl İzlenir?. Ed. Ahmet Buldam, İstanbul: Tesev Yayınları.

Eurostat.(2021). Old-age-dependency ratio. Erişim adresi: https://ec.europa.eu/eurostat/web/products-datasets/-

/tps00198\#: :text=This\%20indicator\%20is\%20the\%20ratio,age\%20(15\%2D64)

Eurostat.(2021b). Expenditure on social protection. Erişim adresi: https://ec.europa.eu/eurostat/databrowser/view/tps00098/default/table?lang=en

Geyik,O.\& Şeren, G. Y. (2021). Vergilerin Sosyal Harcamalar Özelinde Topluma Geri Dönüşü: Türkiye Üzerine Bir Analiz. Aksaray Üniversitesi İktisadi ve İdari Bilimler Fakültesi Dergisi, 13(3) , 17-28. DOI: 10.52791/aksarayiibd.971658

Geyik,O.(2020). Türkiye' de Dezavantajlı Gruplara Yönelik Yapılan Mali Yardımlar Üzerine Bir İnceleme. Ufkun Ötesi Bilim Dergisi 20(1), 52-66.

Government Office for Science. (2016). Future of an Ageing Population. London: Crown copyright, Erişim adresi: https://assets.publishing.service.gov.uk/government/uploads/system/uploads/attachment _data/file/816458/future-of-an-ageing-population.pdf

Hilal,G.(2019). Türkiye'de Kamu Sosyal Koruma Harcamaları Kapsamında Engellilere Yönelik Harcamalar: Karşılaştırmalı Bir Değerlendirme. International Social Sciences Studies Journal, 5(36), 2855-2868. 
ILO. (2014). Social protection for older persons: Key policy trends and statistics. Geneva: ILO publications, Erişim adresi: https://www.ilo.org/wcmsp5/groups/public/---dgreports/--dcomm/documents/publication/wcms_310211.pdf

İlgün,M.F.(2015). Kamu Sosyal Harcamalarının Gelir Dağılımı Üzerindeki Etkisi: OECD Ülkelerine Yönelik Panel Veri Analizi. DEÜ Sosyal Bilimler Enstitüsü Dergisi, 17(4), 493-516.

Koç,Ö.E. (2019). Sosyal Devlet ve Sosyal Bütçe Perspektifinden Türkiye'de Sosyal Harcamalar. Güncel Sosyal ve Mali Sorunlara Yönelik Seçme Yazılar içinde(s.53-76), Ankara: Siyasal Kitapevi.

Koray,M.(2005). Sosyal Politika, Ankara: Ezgi Yayınevi.

Musgrave, R. A. (1959). The Theory of Public Finance. New York: Macmillan.

OECD.(2021a). Elderly population. Erişim adresi: https://data.oecd.org/pop/elderlypopulation.htm

OECD.(2021b). Population projections. Erişim adresi: https://stats.oecd.org/Index.aspx?DataSetCode=POPPROJ\#

OECD.(2021c). Social Spending Data. Erişim adresi: https://data.oecd.org/socialexp/socialspending.htm

OECD.(2015). Ageing in Cities Policy Highlights. Paris:OECD Publishing. Erişim adresi: https://www.oecd.org/cfe/regionaldevelopment/Policy-Brief-Ageing-in-Cities.pdf

Öztürk, M. (2020). Sosyal Harcama Türleri ve Ekonomik Büyüme İlişkisi: Türkiye Örneği, Sosyal Güvenlik, 10(1), 107-124

SBB.(2020a). 2021 Yılı Bütçe Gerekçesi. Ankara, Erişim adresi: https://www.sbb.gov.tr/wpcontent/uploads/2021/02/2021_Yili_Butce_Gerekcesi.pdf

SBB.(2020b).2021-2023 Dönemi Bütçe Hazırlama Rehberi. Ankara, Erişim adresi: https://www.sbb.gov.tr/wp-content/uploads/2020/10/2021-

2023_ButceHaz\%C4\%B1rlamaRehberi.pdf

SBB.(2021a).2021 Yılı Bütçesi Vatandaşın Bütçe Rehberi, Ankara, Erişim adresi: https://www.sbb.gov.tr/wp-content/uploads/2021/04/2021_Vatandasin-Butce-Rehberi.pdf

SBB.(2021b).2021 Yılı Cumhurbaşkanlığı Yıllık Programı. Ankara, Erişim adresi: https://www.sbb.gov.tr/wpcontent/uploads/2020/11/2021_Yili_Cumhurbaskanligi_Yillik_Programi.pdf

Scholz,W.,Cichon,M.,\&Hagemejer, K. (2000). Social Budgeting. International Labour Organization: Geneva.

Silverstein,M.\&Giarrusso, R.(2010). Aging and family life: A decade review. Journal of Marriage and Family, 72(5), 1039-1058.

Spicker, P. (2000). The Welfare State: A General Theory, Sage Publications, London.

Şeker,M. (2011).Yerel Yönetimlerde Sosyal Bütçeyi İzleme Rehberi, İstanbul: Tesev Yayınları.

Taşçı,F.(2010). Yaşlılara Yönelik Sosyal Politikalar: İsveç, Almanya, İngiltere ve İtalya Örnekleri, Çalışma ve Toplum, 1, 177-202. 
Titmuss,R.M. (1974). 'What is Social Policy?', in Brian Abel-Smith and Kay Titmuss (eds), Social Policy: An Introduction içinde (s.23-32), New York, NY: Pantheon Books.

Topuz,S.K. (2009). Türkiye'de Sosyal Devlet Harcamalarının Genel Eğilimi: 2001-2009 Yılları Arasında Yapılan Eğitim, Sağlık ve Sosyal Koruma Harcamaları, Alternatif Politika, 1(1), 115136.

TÜİK.(2020).Sosyal Koruma İstatistikleri 2019. Erişim adresi: https://data.tuik.gov.tr/Bulten/Index?p=Social-Protection-Statistics-2019-33668

TÜİ.(2021a).İstatistiklerle $\quad$ Yaşlılar. Erişim adresi: https://data.tuik.gov.tr/Bulten/Index?p=Elderly-Statistics-2020-37227

UNECE-United Nations Economic Commission for Europe.(2012). Active Ageing, Policy Brief. no:13. Erişim adresi: https://unece.org/fileadmin/DAM/pau/age/Policy_briefs/ECEWG.1.17.pdf

UNFPA-United Nations Population Fund.(2012).Ageing in the Twenty-First Century:A Celebration and A Challenge, New York:UNFPA Publication.

WHO.(2001).Men, ageing and health: achieving health across the life span. World Health Organization. Erişim adresi: https://apps.who.int/iris/handle/10665/66941

WHO.(2014).Active Ageing A Policy Framework. Erişim adresi: https://extranet.who.int/agefriendlyworld/wp-content/uploads/2014/06/WHO-ActiveAgeing-Framework.pdf

WHO.(2021a).Ageing and Health. Erişim adresi: https://www.who.int/news-room/factsheets/detail/ageing-and-health

WHO.(2021b).Health Situation Trends. Erişim adresi: http://origin.searo.who.int/entity/health_situation_trends/data/chi/elderly-population/en/

Yentürk,N. (2018). Sosyal Yardımlardan Güvenliğe Türkiye'nin Kamu Harcamaları(2006-2017). İstanbul: İstanbul Bilgi Üniversitesi Yayınları. 